بر رسى رابطه بين ارتفاع و شيب روند متغيرهاى اقليمى در ايران طى دوره زمانى |9AV-Y0|9

\author{
فاطمه سروش" و فرشاد فتحيان'
}

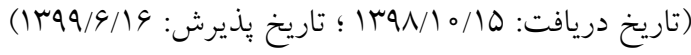

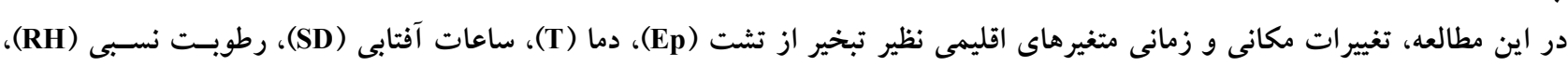

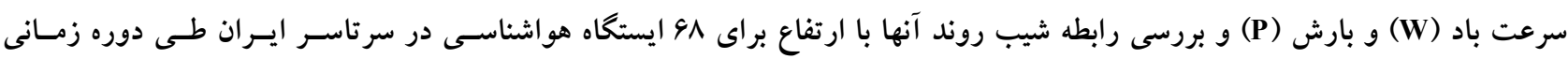

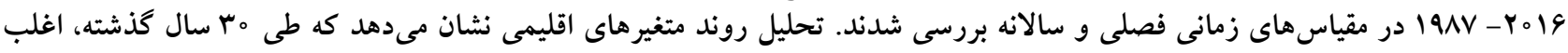

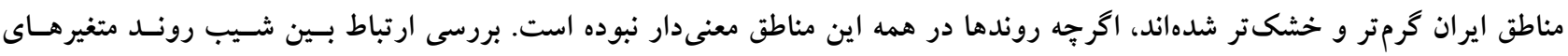

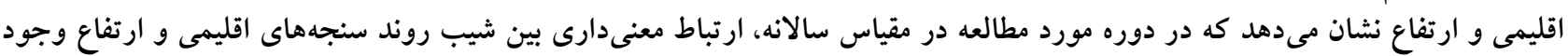

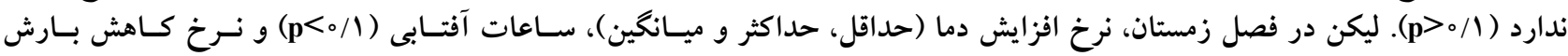

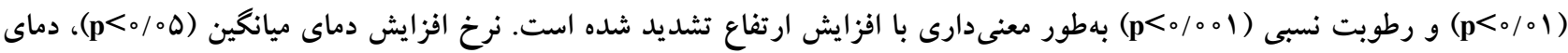

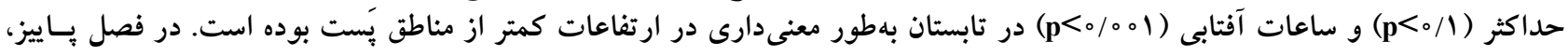

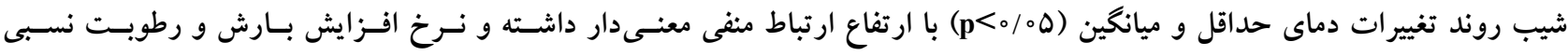

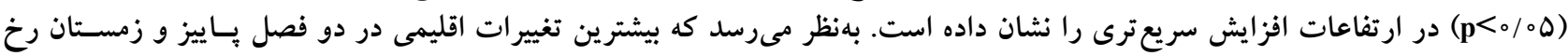

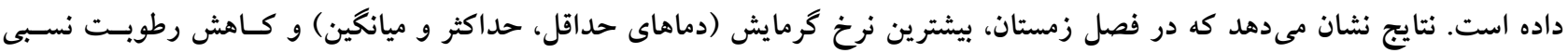

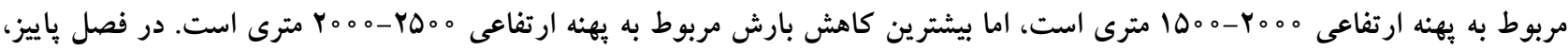

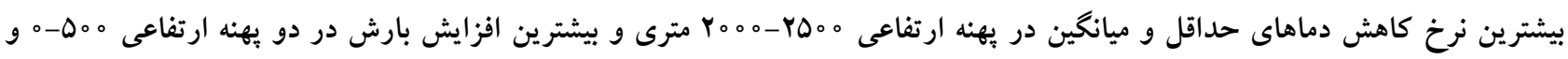
r. Yoo-rDo。

وازههاى كليدى: متغيرهاى آب و هوايى، ارتفاع، شيب روند، ايران.

ا. گروه علوم مهندسى آب، دانشكده كشاورزى، دانشخاه ولىعصر (عج) رفسنجان، ايران *.soroush@vru.ac.ir : مسئول مكاتبات: يُت الكترونيكى 
به ارتفاع در مناطق مرتفـع، رونــــ تغييــات بـارش بــا كراديـان

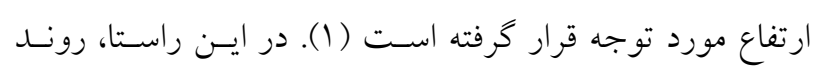
افزايشى بارش با ارتفاع در مقياس سالانه و فصلى (بهار و وياييز)

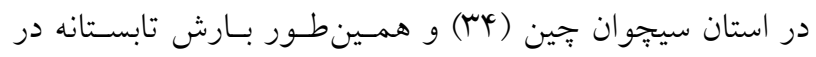

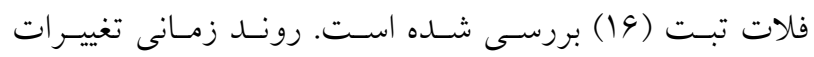

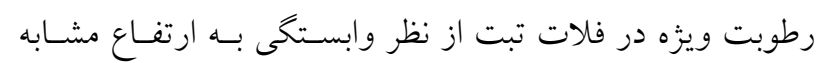

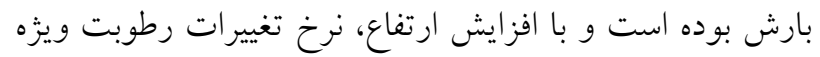

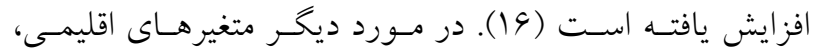

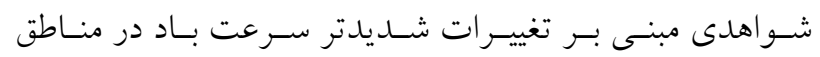

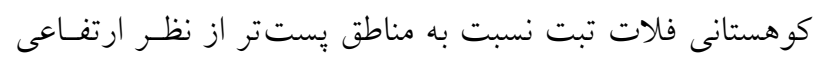

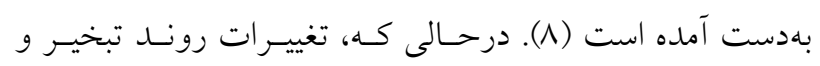

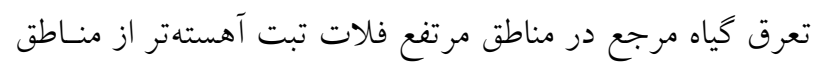

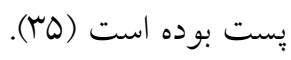
ايران كشورى بزرگ با شرايط اقليمى و جغرافيايى كوناكون إنون

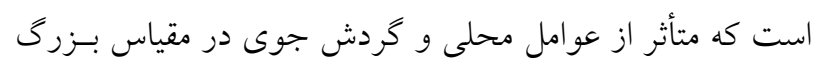

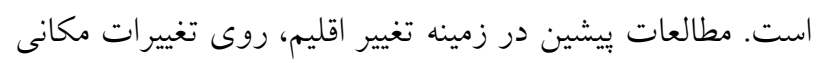

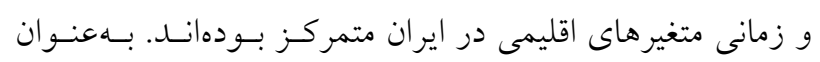

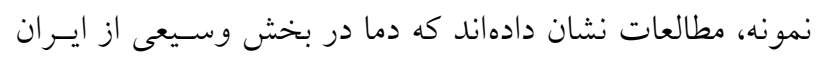

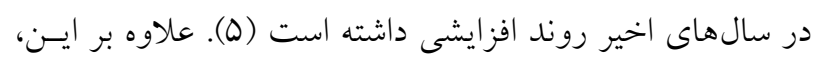

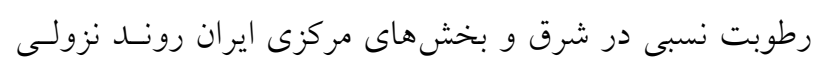

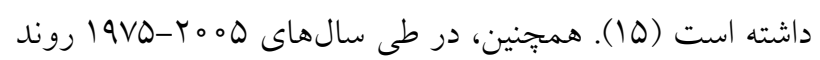

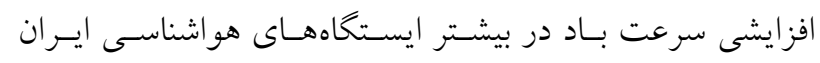

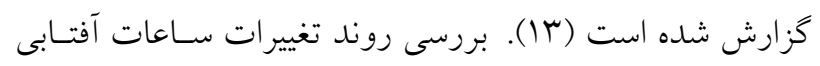

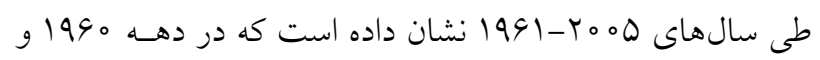

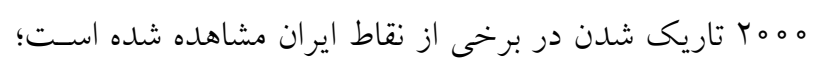

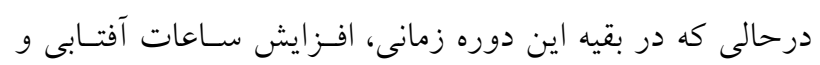

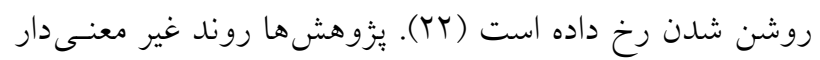

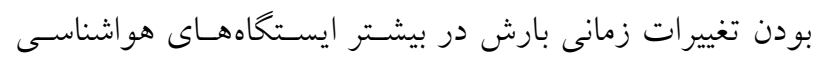

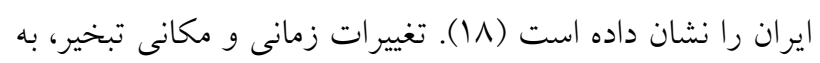

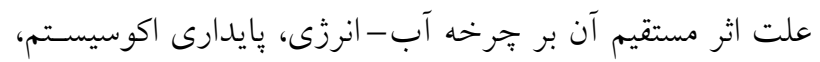

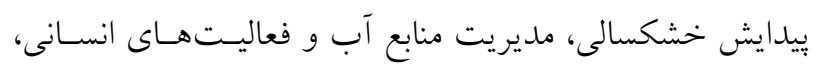

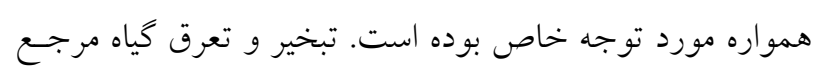

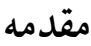

آب و هوا و اقليم يكى منطقه نقش اساسى در زنـدگىى، معيشـت

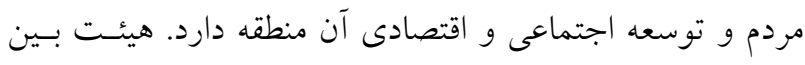
الـدول تغييـر اقلـيم ( Intergovernmental Panel on Climate در ينجمين گزارش ارزيابى خود نشان دادنــ (Change (IPCC) كه سيستمهاى اقليمى بهطور معنى دارى در حسال تغييـر هسـتند

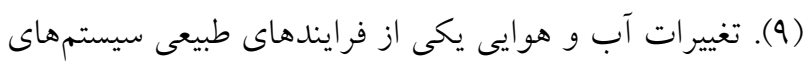

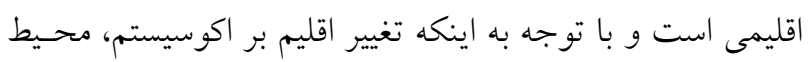

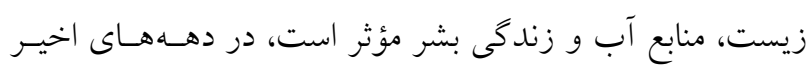

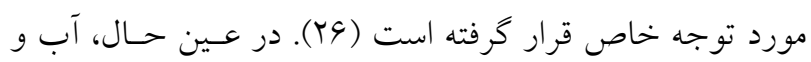

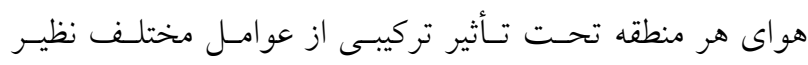

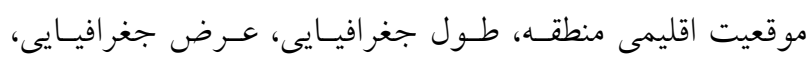

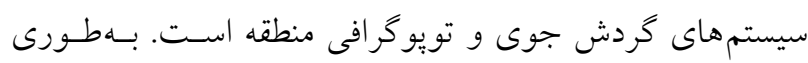

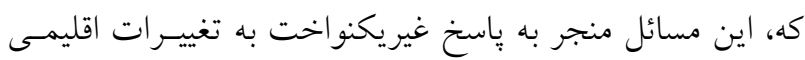

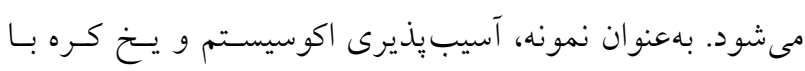

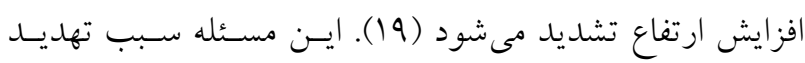

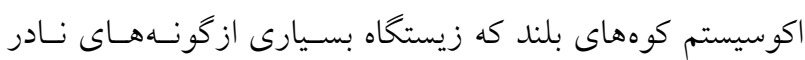

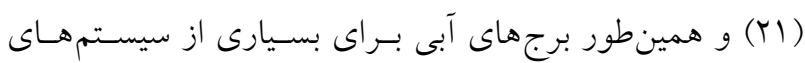

$$
\text { رودخانهاى هستند (Yr)، مىشود. }
$$

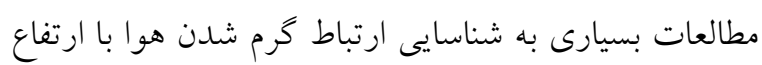

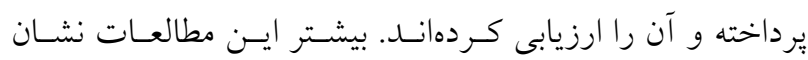

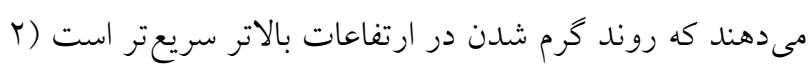

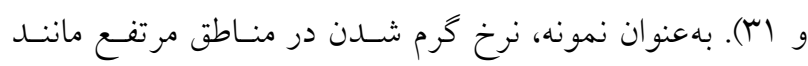

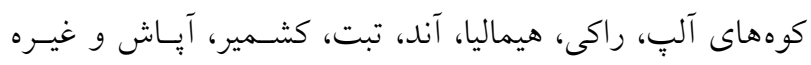

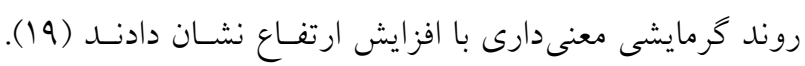

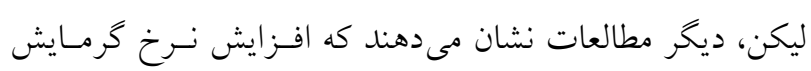

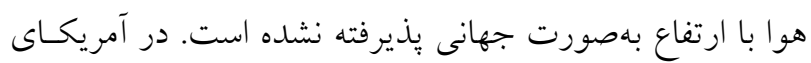

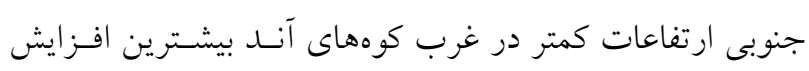
دما را داشته است، درحالى كه نرخ كرمايش در ارتفاعات بيشتر

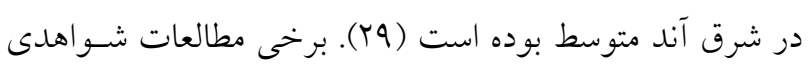

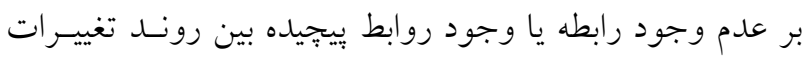

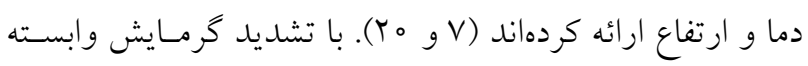


نامهاى دشت كوير و دشت لوت اسـت، مسىشـوند؛ بنـابراين،

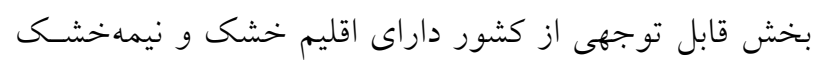

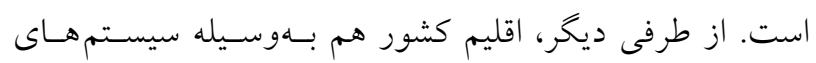
بزرى جوى و هم اثرات محلى هدايت مىشود و ايسن عو امـل فئل

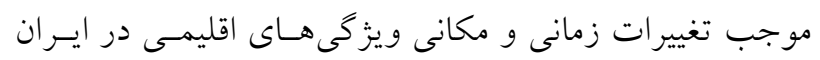

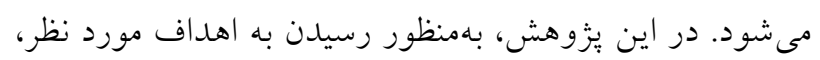

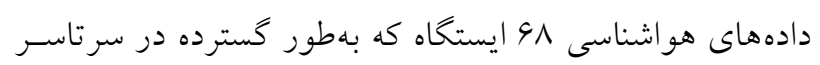

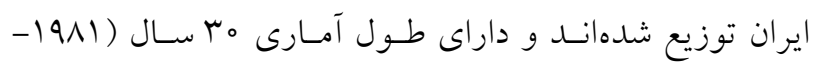

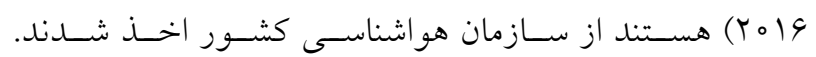

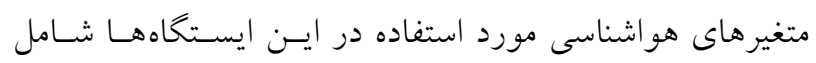

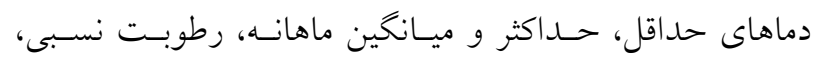

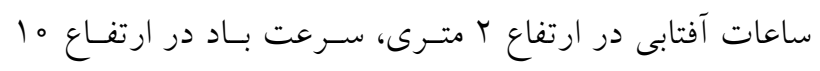

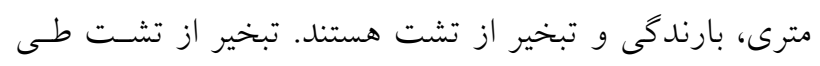

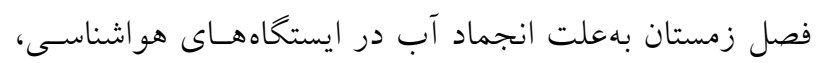

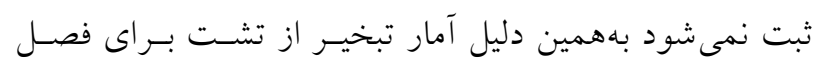

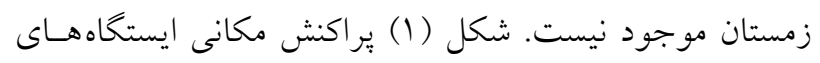

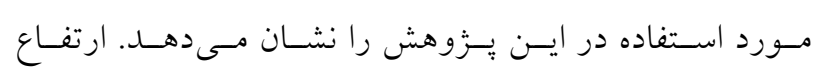

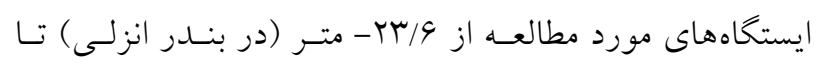

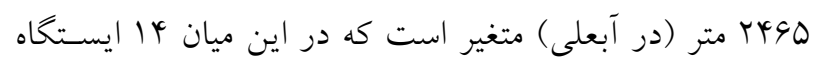

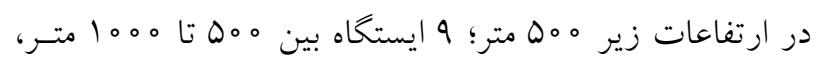

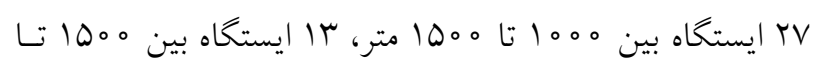

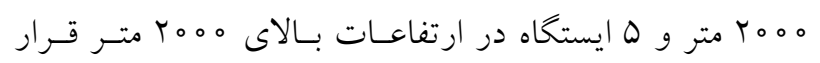

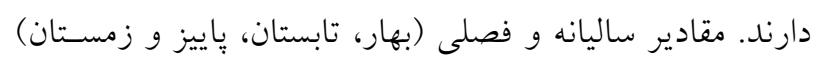

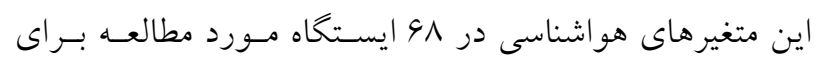

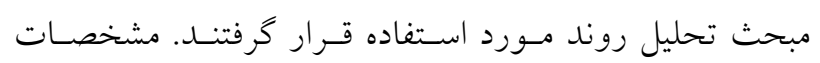

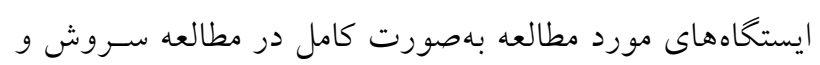

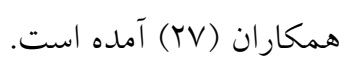

\section{روش ها}

روش تحليل روند من - كندال

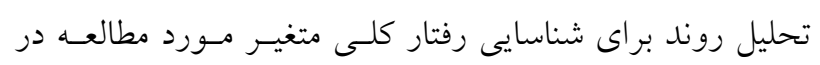

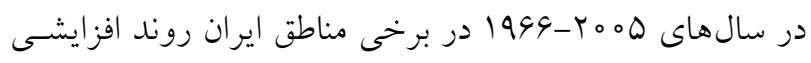

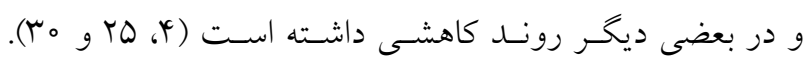
ليكن، با وجود مطالعات بسيار در زمينه بررسى رونـــ تغييـرات

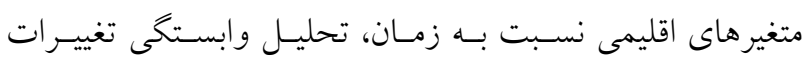

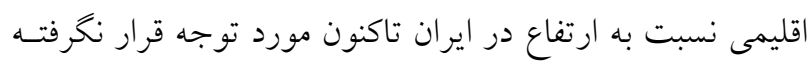

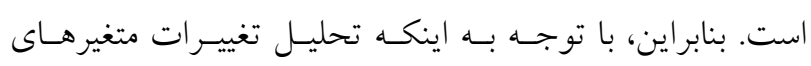

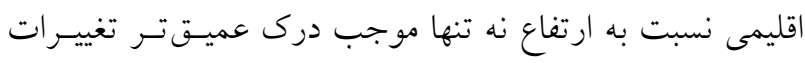

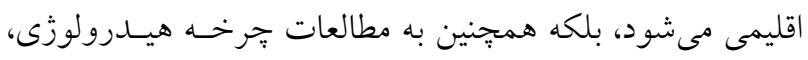

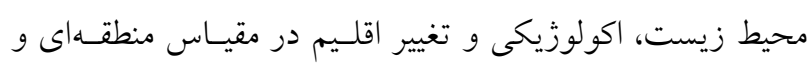

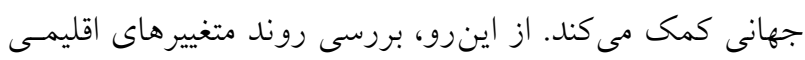

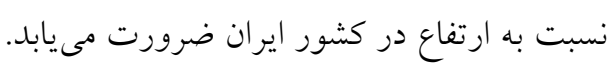

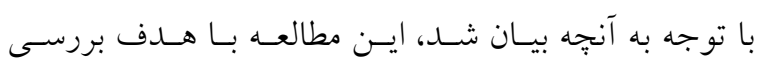

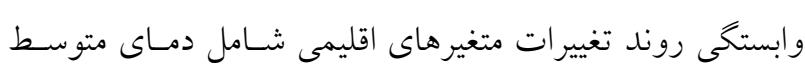

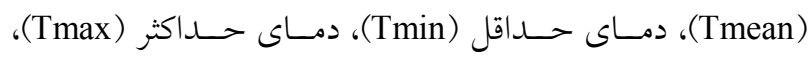

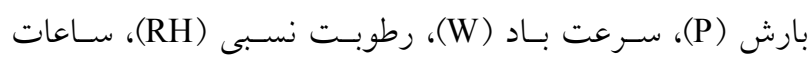

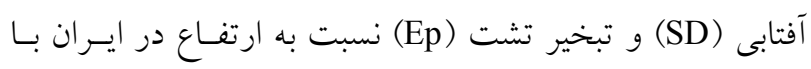

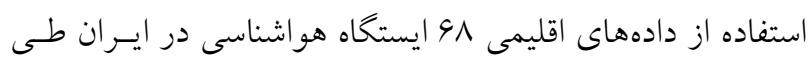

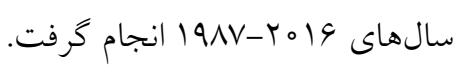

منطقه مطالعاتى و دادههاى اقليمى

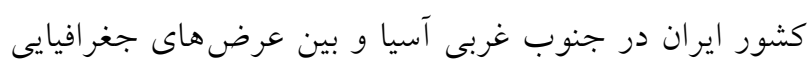

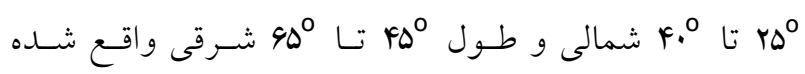

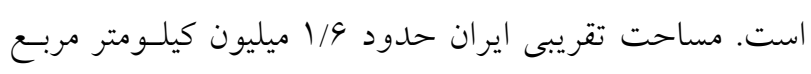
است كه بيش از نيمى از مساحت كشور توسط دو رشته كـوه،

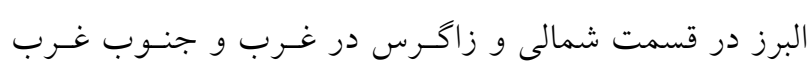

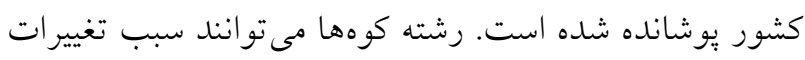

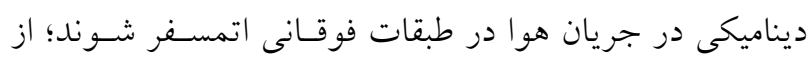

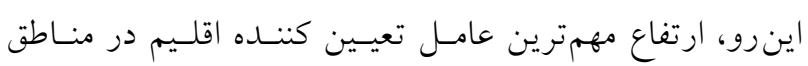

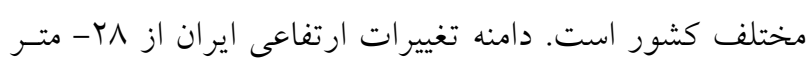

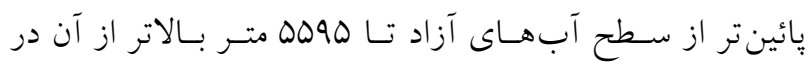

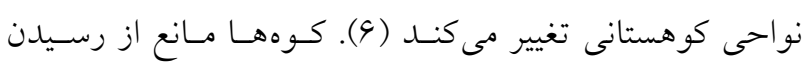

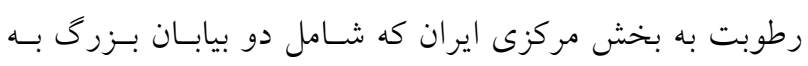




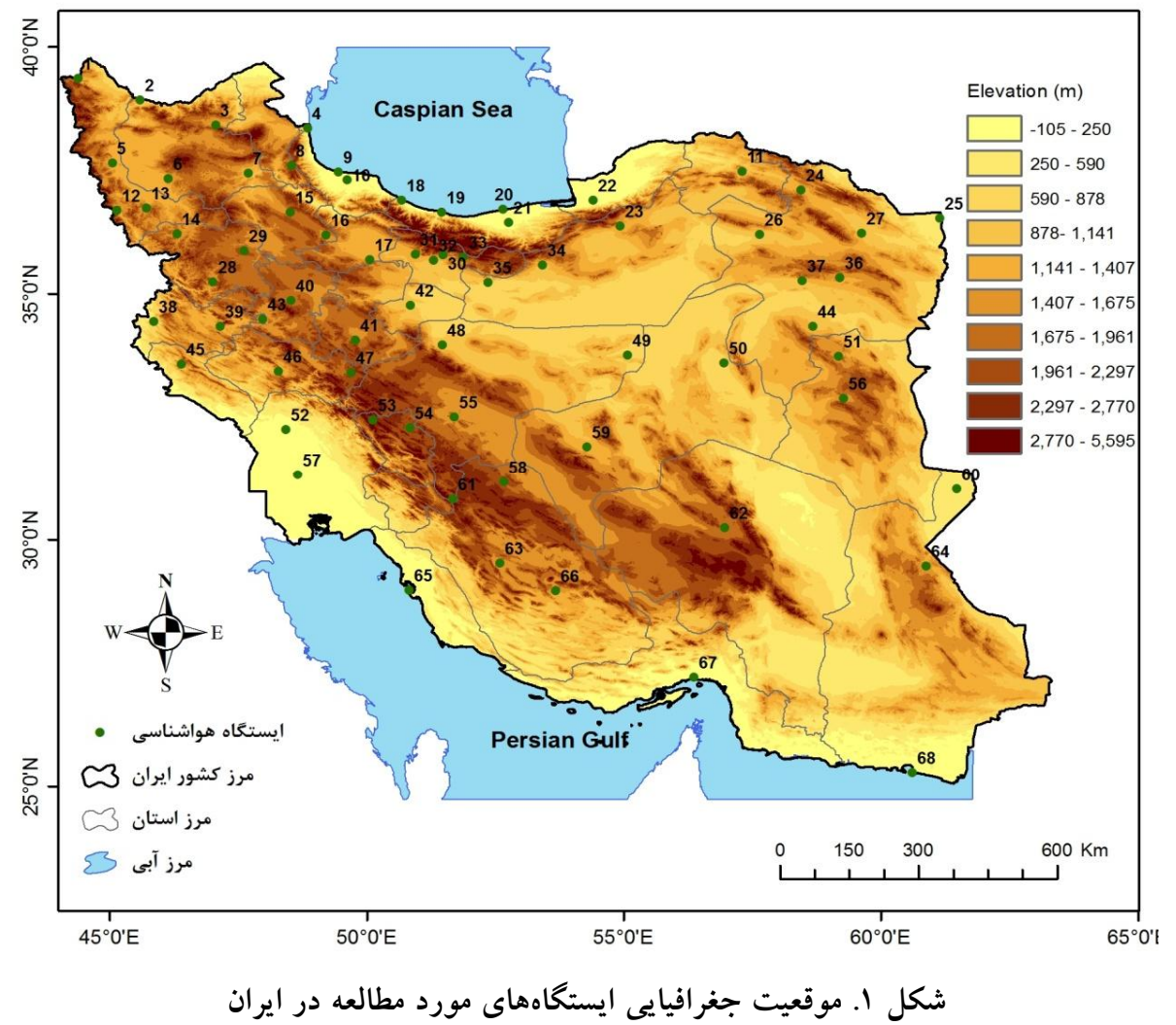

$\operatorname{sgn}\left(x_{j}-x_{k}\right)=\left\{\begin{array}{ccc}+1 & \text { if } & \left(x_{j}-x_{k}\right)>0 \\ 0 & \text { if } & \left(x_{j}-x_{k}\right)=0 \\ -1 & \text { if } & \left(x_{j}-x_{k}\right)<0\end{array}\right.$

سبس، واريانس آماره S از رابطه زير محاسبه مىشود:

$\mathrm{V}(\mathrm{S})=\mathrm{n}(\mathrm{n}-1)(2 \mathrm{n}+5)-\sum_{\mathrm{i}=1}^{\mathrm{m}} \mathrm{t}(\mathrm{t}-1)(2 \mathrm{t}+5) / 18$

كه در آن n تعداد دادهها، m تعداد دستهها با دادههاى گَرهدار و

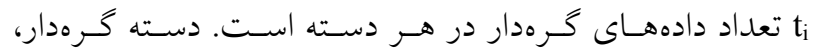

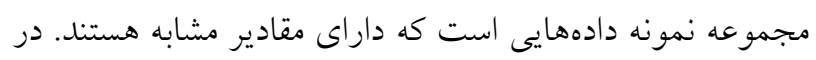
مواردى كه تعداد نمونههـا n>10 باشــ، آمـاره آزمـون نرمـال استاندارد (Z) از رابطه أع محاسبه مىشود:

$Z=\left\{\begin{array}{lll}\frac{S-1}{\sqrt{\operatorname{Var}(S)}} & \text { if } & S>0 \\ 0 & \text { if } & S=0 \\ \frac{S+1}{\sqrt{\operatorname{Var}(S)}} & \text { if } & S<0\end{array}\right.$

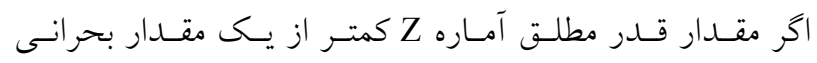

طول دوره زمانى ثبت شده به كار مىرود. در اين يزوهش، بـراى

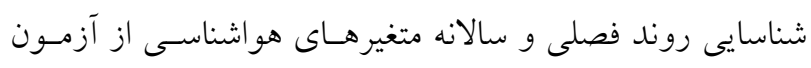

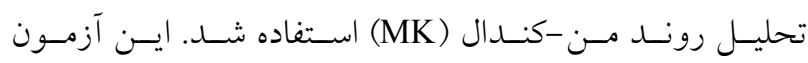
نايارامترى (II و IV IV توسط سازمان هواشناسـى جهانى بـراى ارزيابى دادهاى هيدرولوزيكى و هواشناسى توصيه شده اسـت.

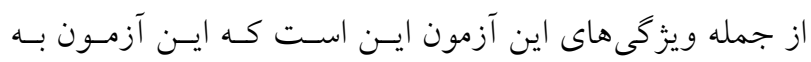

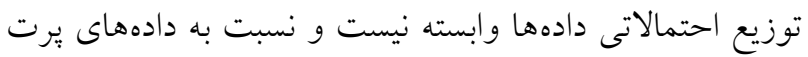

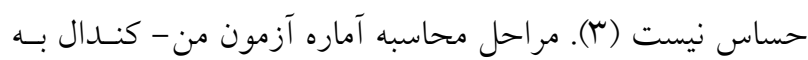

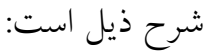

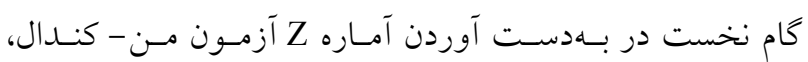
محاسبه آماره S بهصورت رابطه است: $\mathrm{S}=\sum_{\mathrm{k}=1}^{\mathrm{n}-1} \sum_{\mathrm{j}=\mathrm{k}+1}^{\mathrm{n}} \operatorname{sgn}\left(\mathrm{x}_{\mathrm{j}}-\mathrm{x}_{\mathrm{k}}\right)$

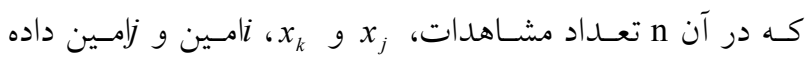

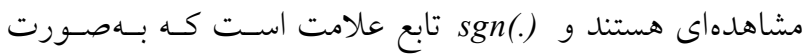

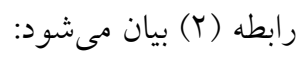


مقدار آن حدود مبr+ ميلى متر در دهـه اسـت. امـا در مـورد

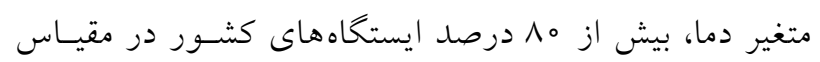
سالانه روند افزايش دماى متوسط، حداكثر و حداقل را نشان

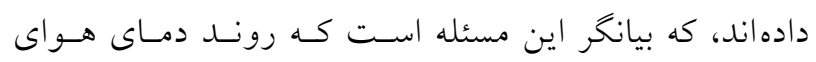
كشور رو به افزايش است، غالب يزوهش هاى انجام شــه در

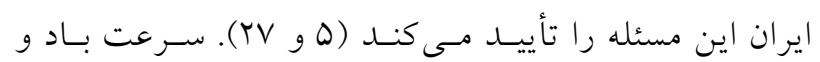

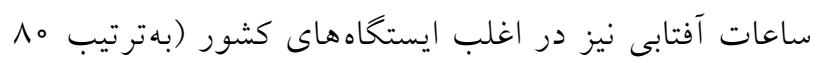

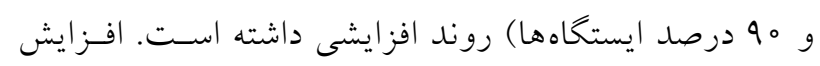
سرعت باد مىتواند منجر به كاهش ابرناكى و افزايش ساعات

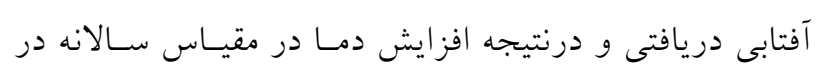
كشور شده باشد. اين امر موجب شده است كه تقريباً در ورئو درصد ايستخاههاى كشور در مقياس سالانه رطوبت نسـبى و بارش كاهش يابد. بررسى متوسط شيب رونـــ سـنجههـاى اقليمسى در مقيـاس فصلى (جدول () نشان مسىدهــ كـه مقـدار دماهـاى حــداقل، حداكثر و ميانگين و همجنين ساعات آنتـابى و سـرعت بـاد در سطح كشور در فصل زمستان بيشترين افزايش را داشته است. با وجود ايسن، مقـدار رطوبـت نسـبى و بـاران در فصـل زمسـتان بيشترين كاهش را نسبت بـه سـاير فصـول در طـى دوره مـورد مطالعه داشته است. تغييرات متغيرهاى اقليمى در فصل زمسـتان مى تواند درنتيجه كاهش ابرناكى در اين فصل باشد كه منجر بـه

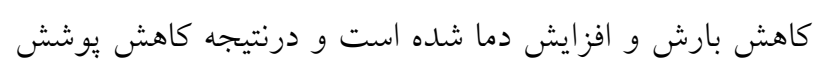
ابر، ساعات آفتابى افزايش يافته است. با توجه به اين مسئله كـه

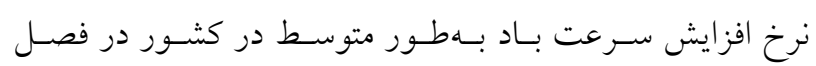
زمستان بيش از ساير فصول بــوده اسـت، افـزايش سـرعت بـاد مى تواند عامل مؤثرى در ايجاد تغييرات اقليمسى مـؤثر در فصـل

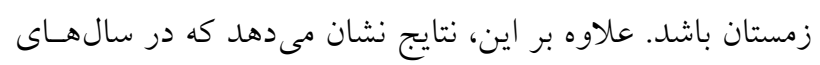

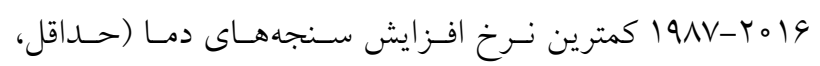

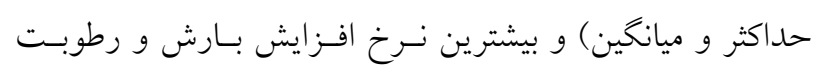

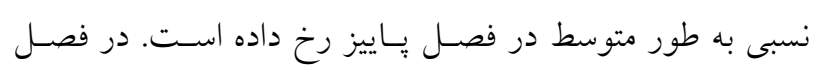

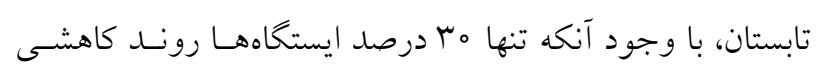

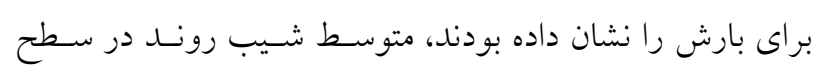

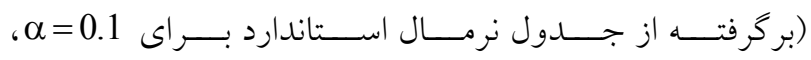

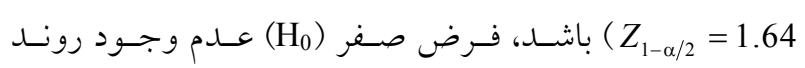
معنسى دار يذيرفتـه مسىشـود، در غيـر ايسنـصـورت، زمـانى كـهـ

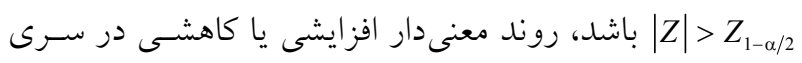
زمانى وجود دارد و فرض صفر رد مىشود. روش تايل - سن

مقدار شيب خط روند با استفاده از روش بيشــهادى تايـل (YN) و سن (YY) كه بهاعنوان تخمين گَر سِـن نيـز ناميـده مسى شـود، محاسبه شد. شيب ميانه تايل - سن يك روش نإِـارامترى بـراى تحليل روند است كه دادهاى برت روى آن اثرى ندارد و شيب

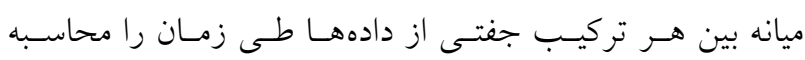
مى كند. براى محاسبه اين شيب، ابتـدا شـيب N N جفـت داده بــ صورت رابطه ه محاسبه مىشود: $\beta_{\mathrm{k}}=\frac{\mathrm{x}_{\mathrm{j}}-\mathrm{x}_{\mathrm{i}}}{\mathrm{j}-\mathrm{i}} \quad \forall 1<\mathrm{i}<\mathrm{j} \quad \mathrm{k}=1, \ldots, \mathrm{N}$ كه در آن و i هســتند، $\mathrm{i}$

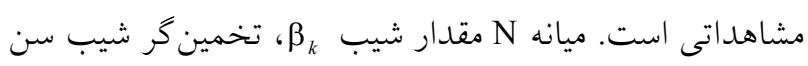

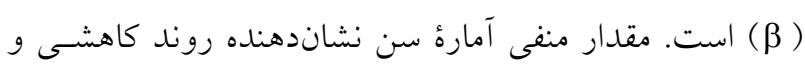
مقدار مثبت آن نشاندهنده رونــد افزايشـى سـرى زمـانى داده مورد مطالعه است.

\section{نتايج و بحث}

\section{تحليل شيب روند متغيرهاى اقليمى}

جزئيات نرخ تغيير متغيرهاى اقليمى در جـدول ( ) آورده شـده است. نتايج نشان مىدهد كه سنجههـاى هواشناسىى در مقيـاس سالانه و فصلى در تعـدادى از ايستخاههـاى هواشناسـى رونـــ افزايشى و در برخى ديخر، روند كاهشى داشتند. بهاعنوان نمونه، بر اساس نتايج مشـاهده مسى شـود كـه در

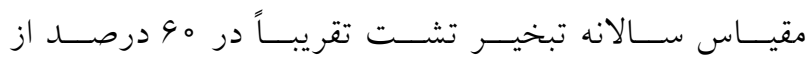
ايستخاههاى كشـور رونـــ افزايشـى داشـته اسـت؛ بنـابراين، متوسط شيب خط رونسد تبتخيـر در كشـور افزايشسى بـوده و 
جدول ا. تعداد ايستخاههاى داراى روند و شيب روند متغيرهاى اقليمى در مقياس فصلى و سالانه در ايران

\begin{tabular}{|c|c|c|c|c|c|c|}
\hline \multirow{2}{*}{ شيب متو سط } & \multicolumn{2}{|c|}{ روند كاهشى } & \multicolumn{2}{|c|}{ روند افزايشى } & \multirow{2}{*}{ زمانى } & \multirow{2}{*}{ متغيرهاى اقليمى } \\
\hline & شيب & تعداد ايستخاه & شيب & تعداد ايستگاه & & \\
\hline$r \circ / 99$ & $-100 / 94$ & $Y Y(1 Q)$ & $91 / T 4$ & $K \psi(Y V)$ & سالانه & \multirow{5}{*}{ Ep (mm/decade) } \\
\hline G/Vq & - & rr(11) & ET/VV & TG(YG) & بهار & \\
\hline $1 / 91$ & $-k r / \Lambda q$ & $\operatorname{rr}(19)$ & Tr/GT & rG $(T \Delta)$ & تابستان & \\
\hline$-9 / 11$ & $-19 / \pi V$ & $r \circ(Y)$ & $\mid r / 9 V$ & $r \wedge(11)$ & ياييز & \\
\hline- & - & - & - & - & زمستان & \\
\hline $0 / \pi q$ & $-0 / Y_{0}$ & $M(Y)$ & $0 / 41$ & $09(49)$ & سالانه & \multirow{5}{*}{$\begin{array}{c}\text { دماى ميانخين } \\
\text { Tmean ( }\left({ }^{\circ} \mathrm{C} / \text { decade }\right)\end{array}$} \\
\hline $0 / \mu_{0}$ & $-0 / T Y$ & $9(1)$ &.$/ 49$ & $0 Q(K \mu)$ & بهار & \\
\hline$\circ / T Q$ & $-0 / \mu 1$ & $\mathrm{IV}(\mathrm{V})$ & $0 / 4 x$ & $01(14)$ & 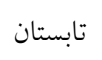 & \\
\hline$-0 / 10$ & $-o / \mu r$ & $r \Delta(q)$ &.$/ \mathrm{V}$ & $M r(V)$ & ياييز & \\
\hline ०/^צ & - & $\circ$ & $\circ / 19$ & $\Delta G(K Y)$ & زمستان & \\
\hline $0 / 4 T^{2}$ & $-0 / r^{4}$ & $\varphi(r)$ & $.0 / 01$ & $G Y(\Delta V)$ & سالانه & \multirow{5}{*}{$\begin{array}{c}\text { دماى حداقل } \\
\text { Tmin ( }\left({ }^{\circ} \mathrm{C} / \text { decade }\right)\end{array}$} \\
\hline$\circ / 09$ & $-o / \mu x$ & $\Delta(Y)$ & $0 / 99$ & $G \mu(\Delta \Lambda)$ & بهار & \\
\hline $0 / 40$ & $-0 / 49$ & $\wedge(\Delta)$ & $\circ / 0 V$ & $9 \circ(01)$ & تابستان & \\
\hline $0 / 1 r$ & $-0 / 49$ & $r \circ(\Delta)$ & $\circ / \mu_{0}$ & $r \varphi\left(Y_{0}\right)$ & ڤֶاييز & \\
\hline$\circ / \wedge Q$ & $-0 / 00$ & $r(\circ)$ & $\circ / \Lambda \Lambda$ & $\Delta \psi(k \varphi)$ & زمستان & \\
\hline$\circ / \Delta Q$ & $-0 / 00$ & $1(\circ)$ & $\circ / \Delta V$ & $q V(q 4)$ & سالانه & \multirow{5}{*}{$\begin{array}{c}\text { دماى حداكثر } \\
\left.\text { Tmax ( }{ }^{\circ} \mathrm{C} / \text { decade }\right)\end{array}$} \\
\hline $0 / 94$ & $-0 / / 4$ & $1(0)$ & $0 / 94$ & $9 V(9 Y)$ & بهار & \\
\hline $0 / \mathbb{F V}$ & $-0 / 09$ & $r(\circ)$ & $0 / 49$ & $99(\Delta Y)$ & تابستان & \\
\hline$\circ / 10$ & $-0 / 14$ & $I V(0)$ & $\circ / \Lambda$ & $\Delta \circ(\varphi)$ & ياييز & \\
\hline $1 / \mu_{0}$ & - & 。 & $1 / \mu_{0}$ & $\Delta \varphi(\Delta \varphi)$ & زمستان & \\
\hline$-0 / \wedge 9$ & $-1 / 94$ & $r q(r V)$ & $0 / 91$ & $19(9)$ & سالانه & \multirow{5}{*}{$\begin{array}{c}\text { رطوبت نسبى (percent/decade) } \\
\text { RH }\end{array}$} \\
\hline$-o / V^{Y}$ & $-1 / 40$ & $\forall \wedge(\mid Y)$ & $1 / 10$ & $19(Y)$ & بهار & \\
\hline$-1 / 49$ & $-1 / \wedge \Delta$ & $Y Q(Y Q)$ & $1 / 09$ & $r r(V)$ & ت ت ت ابستان & \\
\hline$\circ / 09$ & $-1 / T \Lambda$ & $1 \Lambda(0)$ & $1 / 99$ & $\Delta \circ(\varphi)$ & پاييز & \\
\hline$-Y / \circ D$ & $-Y / Q 1$ & $Y \wedge\left(M^{\prime}\right)$ & $\circ / N 1$ & $\Lambda(Y)$ & زمستان & \\
\hline$\Delta Y / I V$ & $-r Y / 00$ & $9(1)$ & G०/Mr & $G Y(r V)$ & سالانه & \multirow{5}{*}{$\begin{array}{c}\text { ساعات آفتابى } \\
\text { SD (hr/decade) }\end{array}$} \\
\hline$-0 / 99$ & $-9 / 90$ & $r \Delta(\varphi)$ & $11 / 99$ & $\mu(\varphi)$ & بهار & \\
\hline$\Lambda / \Lambda$ & $-10 / 49$ & $r \varphi(1 T)$ & $|V / T|$ & $\operatorname{Fr}(T Q)$ & ت ت تابستان & \\
\hline $10 / 90$ & $-Q / 9 \varphi$ & $\operatorname{IV}(r)$ & $10 / T Y$ & $01(10)$ & ياييز & \\
\hline KE/TY & $-r / \Lambda 1$ & $r(\circ)$ & rV/QT & Dr(YT) & زمستان & \\
\hline $0 / T^{\mu}$ & $-0 / T \mu$ & $1 Y(9)$ & $\circ \pi \Delta$ & $\Delta G(K Y)$ & سالانه & \multirow{5}{*}{ 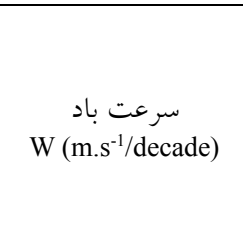 } \\
\hline $0 / \pi 1$ & -o/Mr & $19(9)$ & $\circ / 4$ & $\Delta r(\Gamma \wedge)$ & بهار & \\
\hline$\circ / Y_{0}$ & $-0 / T q$ & $\operatorname{IV}(10)$ & $\circ \mu \Delta$ & $\Delta 1\left(\Gamma_{\Lambda}\right)$ & ت ت تابستان & \\
\hline $0 / \pi 1$ & $-0 / T 9$ & $\| \mu(\wedge)$ & $\circ / \mu_{0}$ & $\Delta \Delta(r \Delta)$ & קֶاييز & \\
\hline$\circ / \pi \Delta$ & - - ه & $\varphi(r)$ & $0 / K_{0}$ & $\Delta r(F))$ & زمستان & \\
\hline$-I Y / A V$ & $-Y Y / Q_{0}$ & $F \mid(\mid Y)$ & $1 N / \kappa^{\circ}$ & $T V(I T)$ & سالانه & \multirow{5}{*}{$\begin{array}{c}\text { بارش } \\
\text { P (mm/decade) }\end{array}$} \\
\hline $0 / M V$ & $-\psi / V \psi$ & Mr(q) & $\Delta / \circ \Delta$ & rq $(\Lambda)$ & بهار & \\
\hline$-1 / 4$ & $-1 Y / Y 4$ & $r Y(\Delta)$ & $1 / 4 x$ & $\operatorname{lq}(11)$ & ت ت ت ابستان & \\
\hline ( & $-\psi / \mu y$ & $\Lambda(\mathcal{H})$ & $11 / 10$ & $\Delta \circ(\mid r)$ & باييز & \\
\hline$-\mid Q / 0 \Lambda$ & $-19 / T V$ & $k q(Y V)$ & $10 / K Y$ & $V(1)$ & زمستان & \\
\hline
\end{tabular}

اعداد داخل ثيرانتز تعداد ايستخاهها دار ایى روند معنى دار در سطح اطمينان ه9 درصد را نشان مىدهند. 
بين تبخيـر از تشـت و ارتفــاع در مقيـاس فصـلى و سـالانه

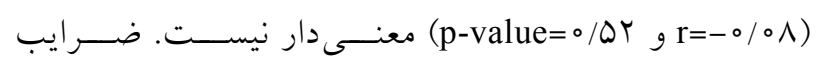

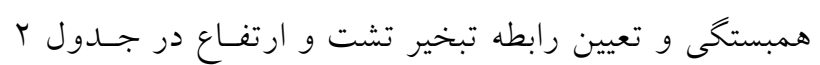

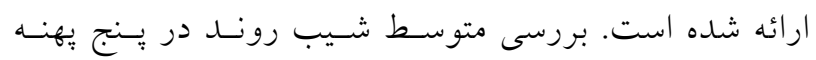

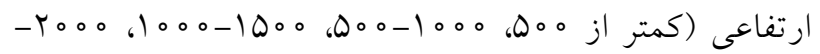

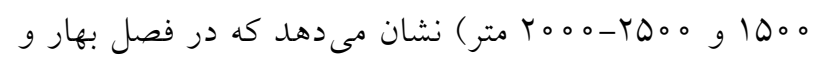
تابستان و همجِنين در مقياس سالانه متوسط شـيب رونـد در

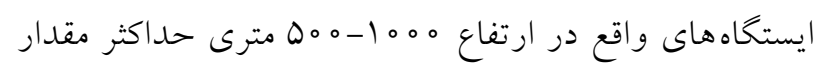
بوده، اما در فصل باييز بين بيهنه ارتفـاعى يـاد شـده و سـاير دامنه هاى ارتفاعى از نظر تغييـرات يتانسـيل تبخيـر تفـاوتى

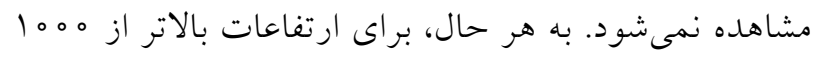
متر با افزايش ارتفاع ايستخاهها، از ميزان شيب رونـــ تبخيـر آنها در تمامى مقياس هاى زمانى كاسته شده است (شكل Y). بررسى سنجههاى اقليمى مؤثر بر تبخير نشـان مسىدهــ كـه

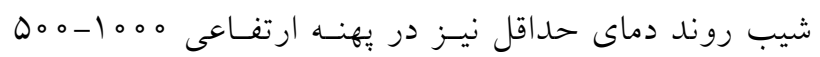
حداكثر بوده است، بنابراين بهنظر مى رسد دماى حــداقل بـر تغييرات تبخير تشت نسبت به ارتفاع مؤثر بوده اسـت (YV).

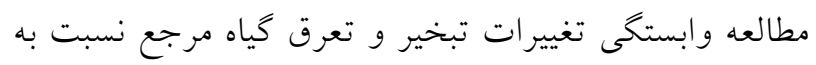

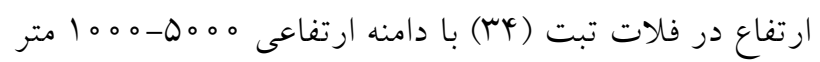
نيز نشان داده است كه تغييرات تبخير و تعرق گياه مرجع در مناطق مرتع كمتر از مناطق يُت بوده است كه با نتايج ايسن مطالعه همخو انى دارد.

ارتباط روند دما- ارتفاع

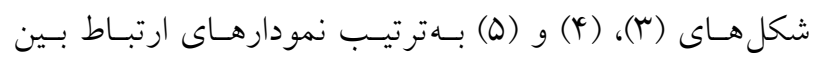
ارتفاع و شيب رونـــ دمـاى ميـانخين، حسـاقل و حســاكثر را در مقياسهاى زمانى فصلى و سالانه نشـان مسىدهـد. ارتبـاط بـين ارتفاع و شيب روند دماى ميانخين در مقيـاس سـالانه و فصـول بهار، تابستان و ياييز منفى است (شكل س). البته همبسـتخى بـين r=-0/09 r ارتفاع و شيب روند دماى ميانخين در مقياس سـالانه

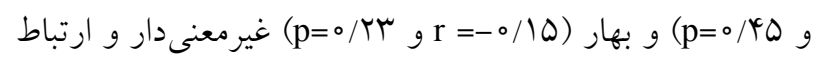

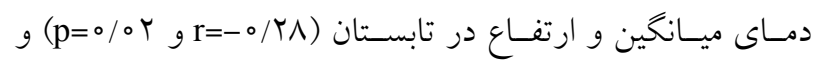

بررسى ها نشان مىدهد بيشتر بارشهـاى تابسـتانه در ايسران مربوط به نوار شمالى كشور و ايستخاههـاى رشـت، رامسـر، آستارا، گرخيل، بندر انزلى و نوشهر بـوده اسـت كـه مقـدار

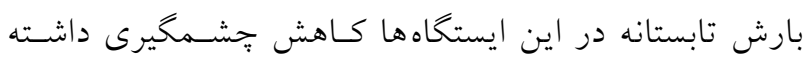

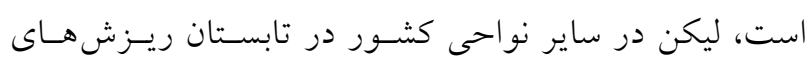
جوى وجود نداشته يا نـاجيز بـوده اسـت كـه در آنهـا تنهـا

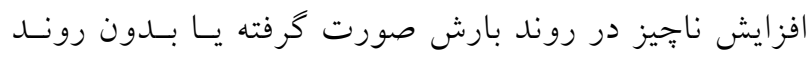
بوده است؛ لذا بهصورت ميـانخين، نـرخ بـارش در تابستان رونــــ كاهشـى داشـته اسـت. يـيش از ايسـن، مطالعـاتى در مقياس هاى زمانى و مكانى مختلف در سطح ايران در زمينسه روند تغييرات زمانى سنجههاى اقليمى صورت كرفته اسـت.

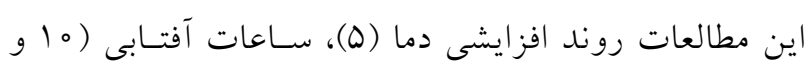

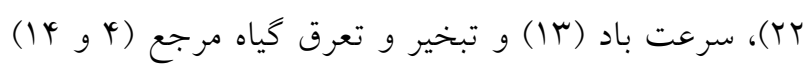

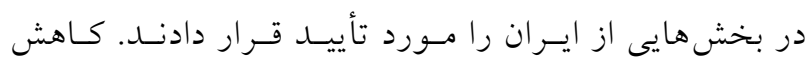
رطوبت نسبى درنتيجه افزايش دما نيز در توافق با مطالعـات

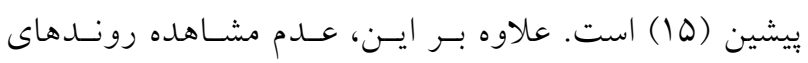
معنى دار بارش در ايران توسط برخى بزوهشخران تأييد شده

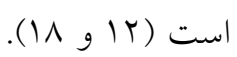

تغييرات روند متغيرهاى اقليمى با ارتفاع به منظور بررسى تغييـرات رونـــ متغيرهـاى اقليمسى بـا ارتفــاع،

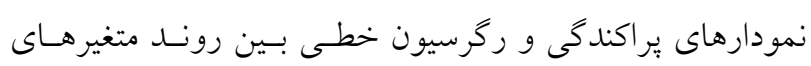
اقليمى و ارتفـاع (سـتون سـمت راسـت شـكل هــاى ب تـا 9) و نمودارهاى متوسط شيب روند متغيرهاى اقليمسى در هـر بهنـاى

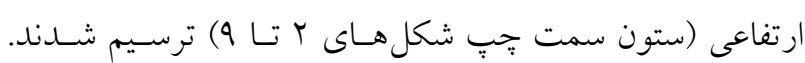

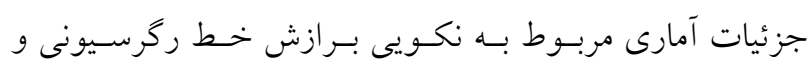

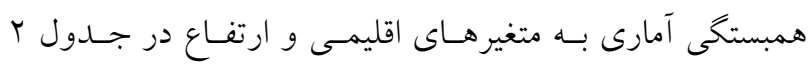

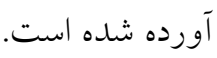

\section{ارتباط روند تبخير از تشت- ارتفاع}

نمودار بر اكندكى شيب روند تغييرات تبخير نسبت به ارتفاع

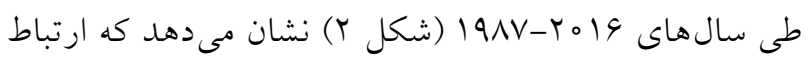



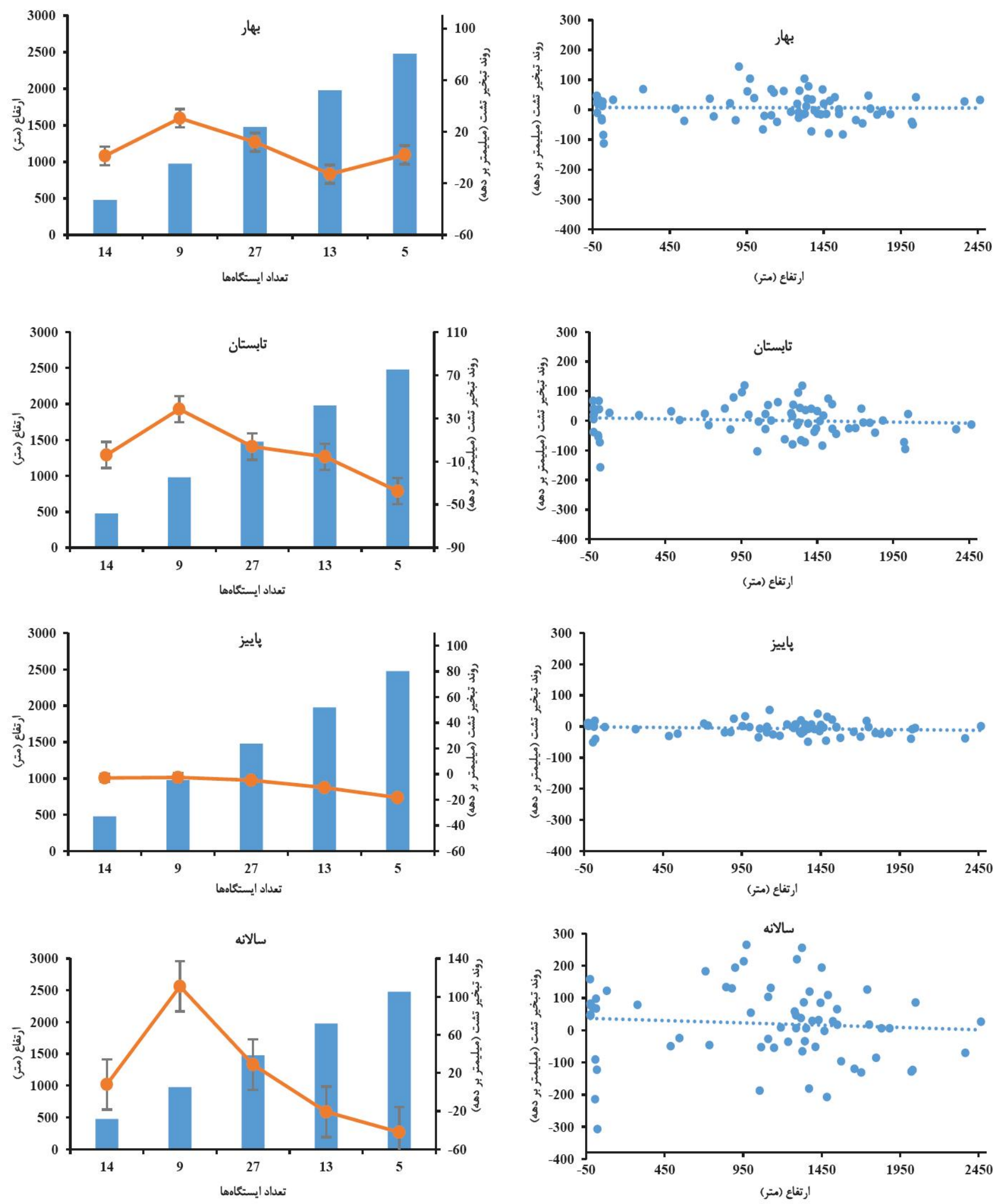

شكل r. نمودارهاى ارتباط بين شيب روند تبخير از تشت و ارتفاع در مقياسهاى زمانى فصلى و سالانه 

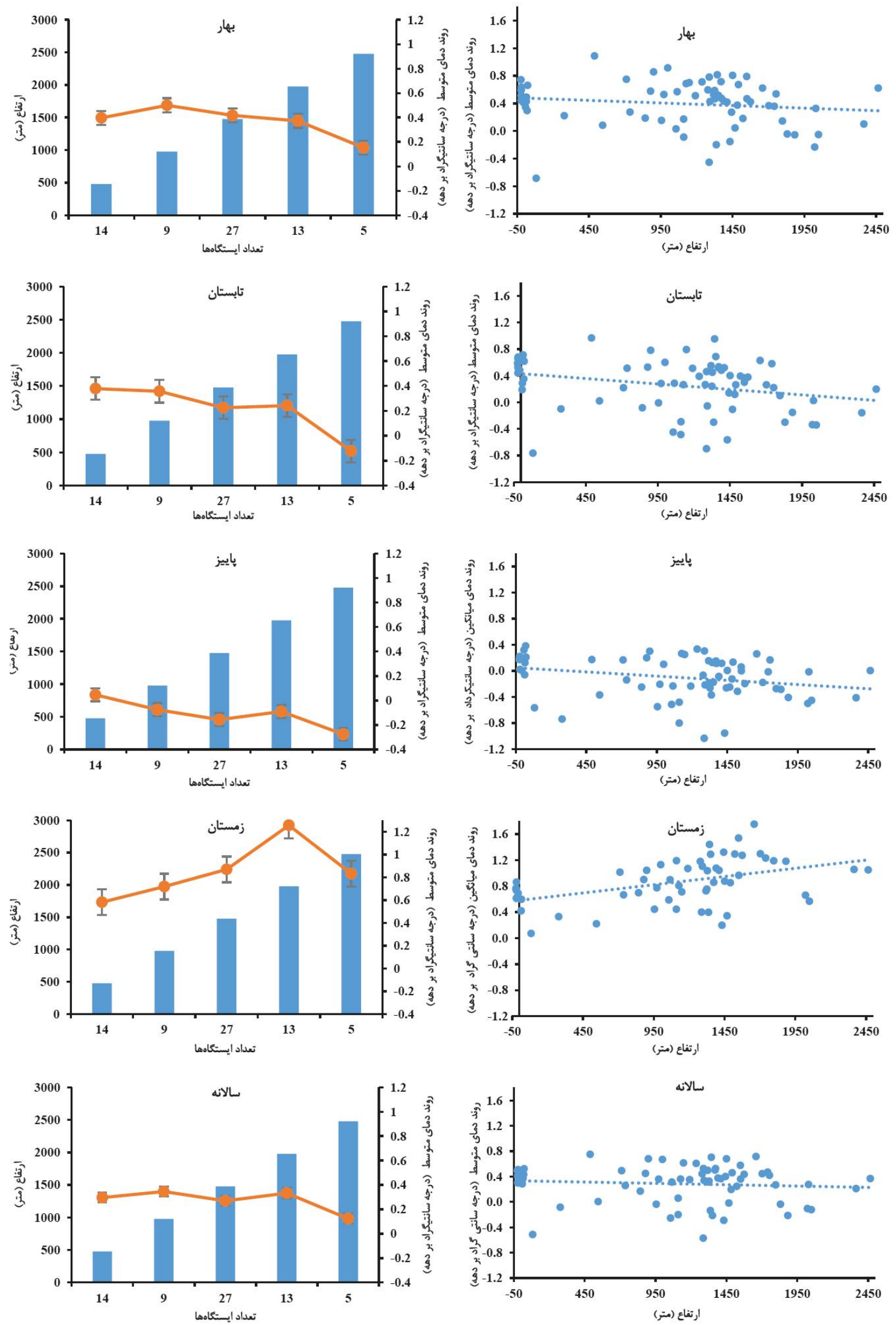

شكل r. نمودارهاى ارتباط بين دماى متوسط و ارتفاع در مقياسهاى زمانى فصلى و سالانه 

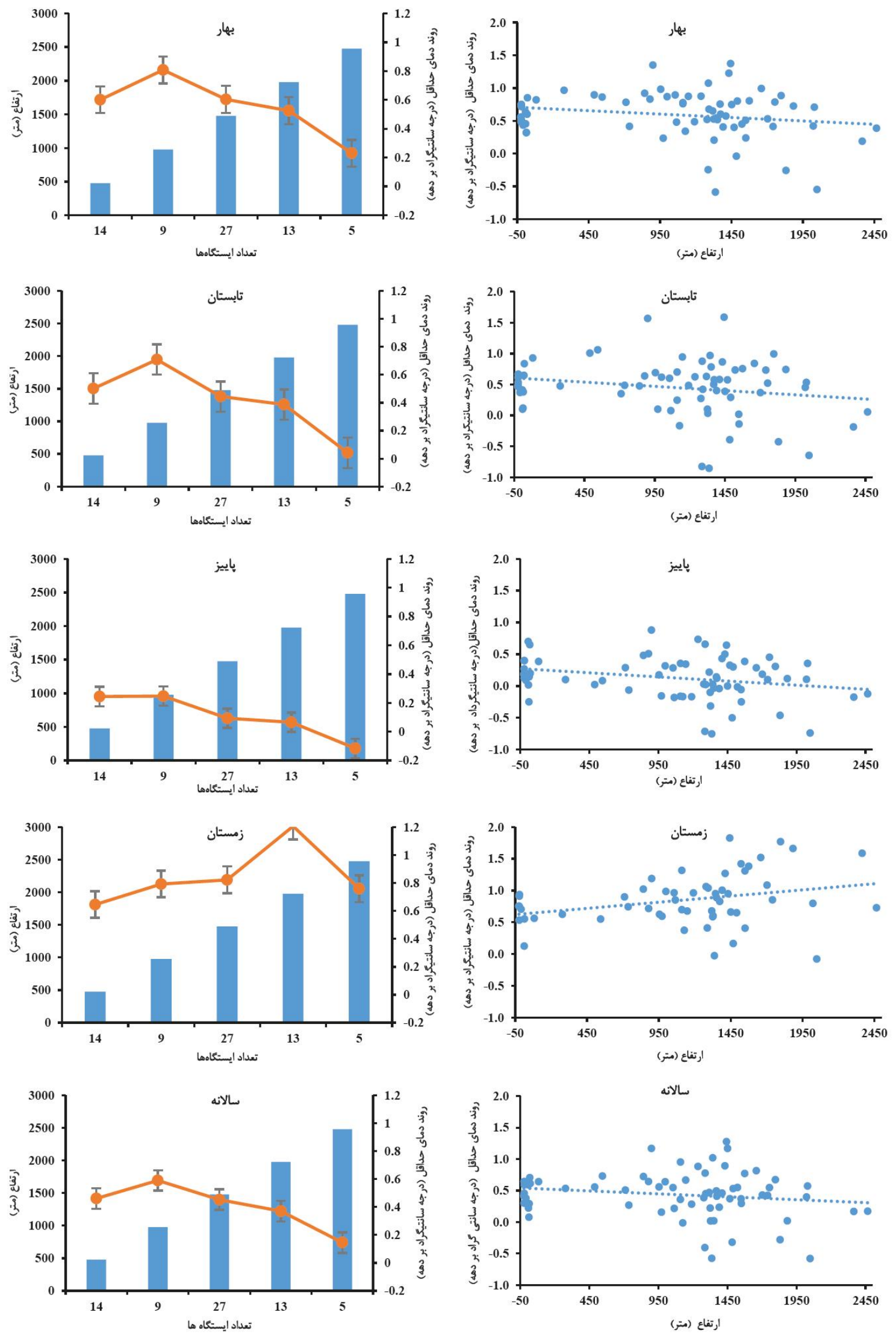

شكل fا. نمودارهاى ارتباط بين دماى حداقل و ارتفاع در مقياسهاى زمانى فصلى و سالانه 

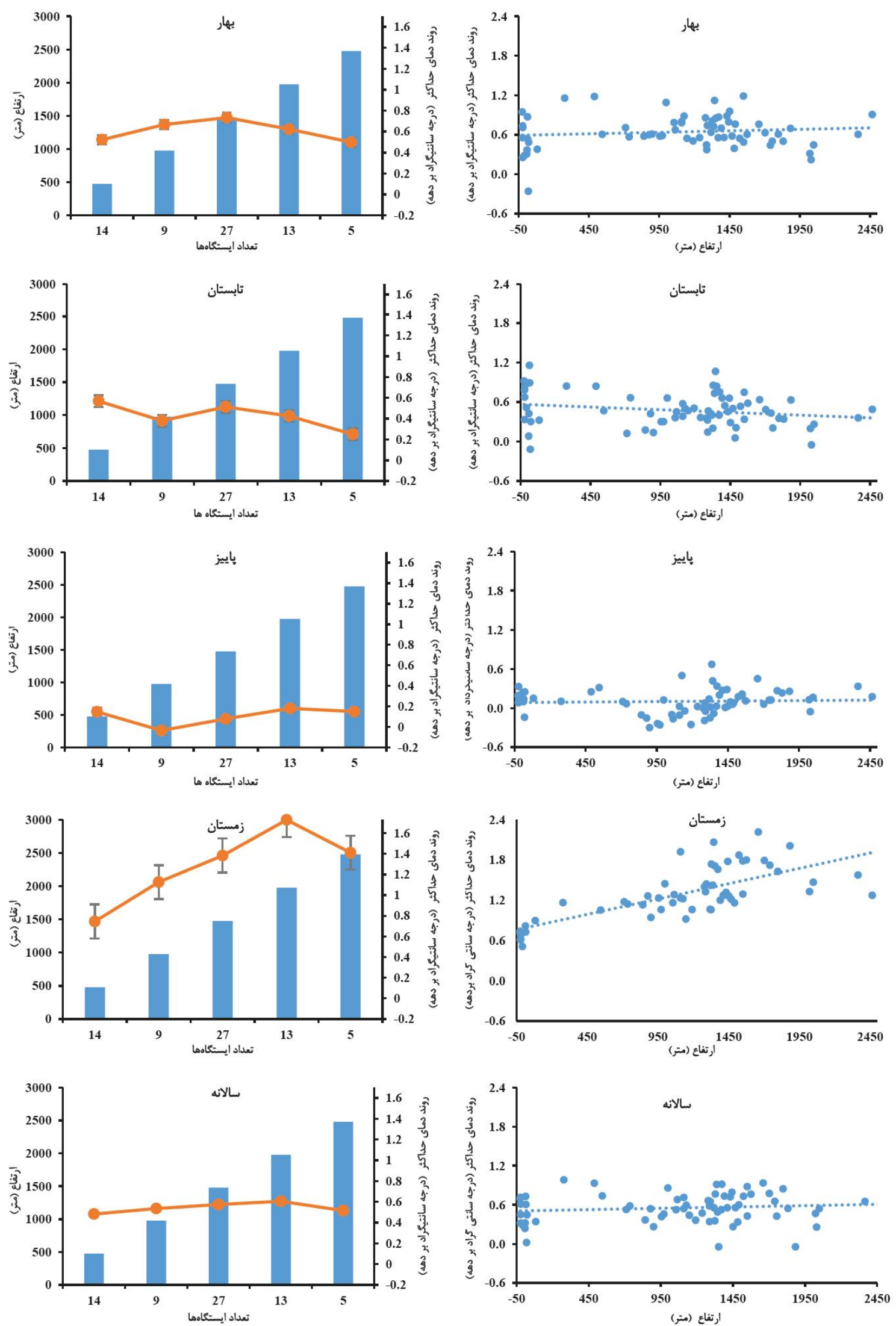

شكل ه. نمودارهاى ارتباط بين دماى حداكثر و ارتفاع در مقياسهاى زمانى فصلى و سالانه 

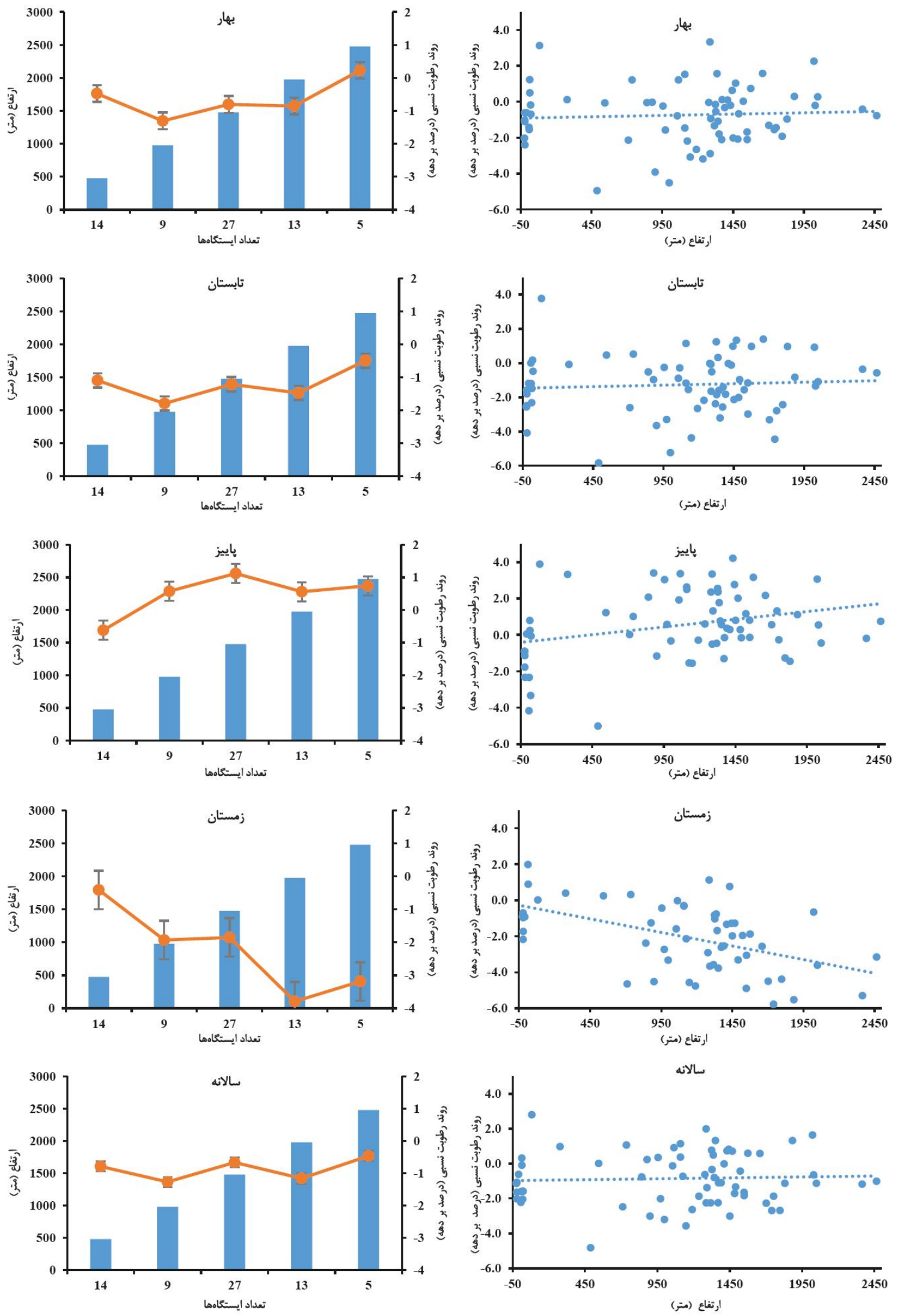

شكل 9. نمودارهاى ارتباط بين رطوبت نسبى و ارتفاع در مقياسهاى زمانى فصلى و سالانه 

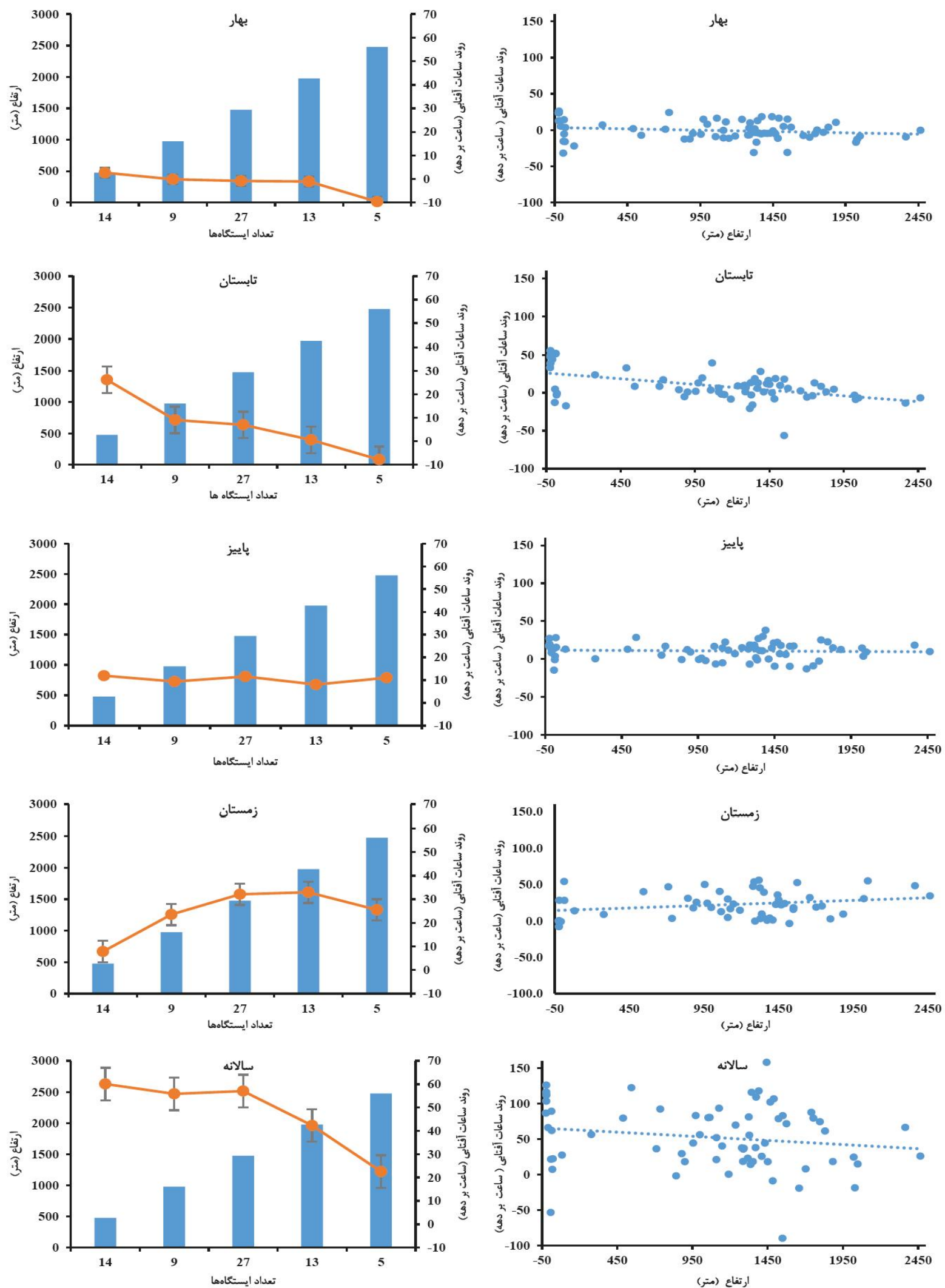

شكل V. نمودارهاى ارتباط بين ساعات آفتابى و ارتفاع در مقياسهاى زمانى فصلى و سالانه 

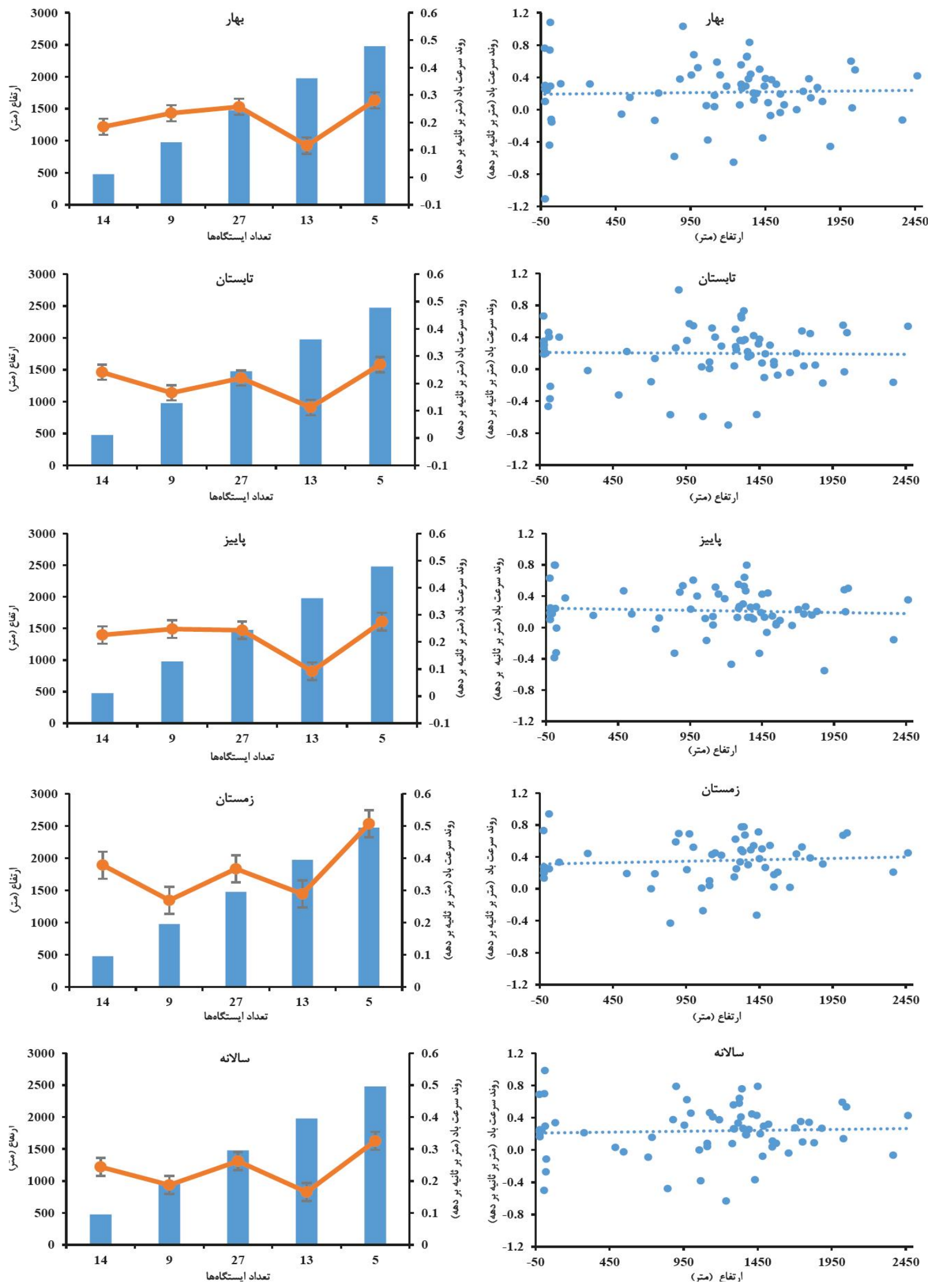

شكل ^. نمودارهاى ارتباط بين سرعت باد و ارتفاع در مقياسهاى زمانى فصلى و سالانه 

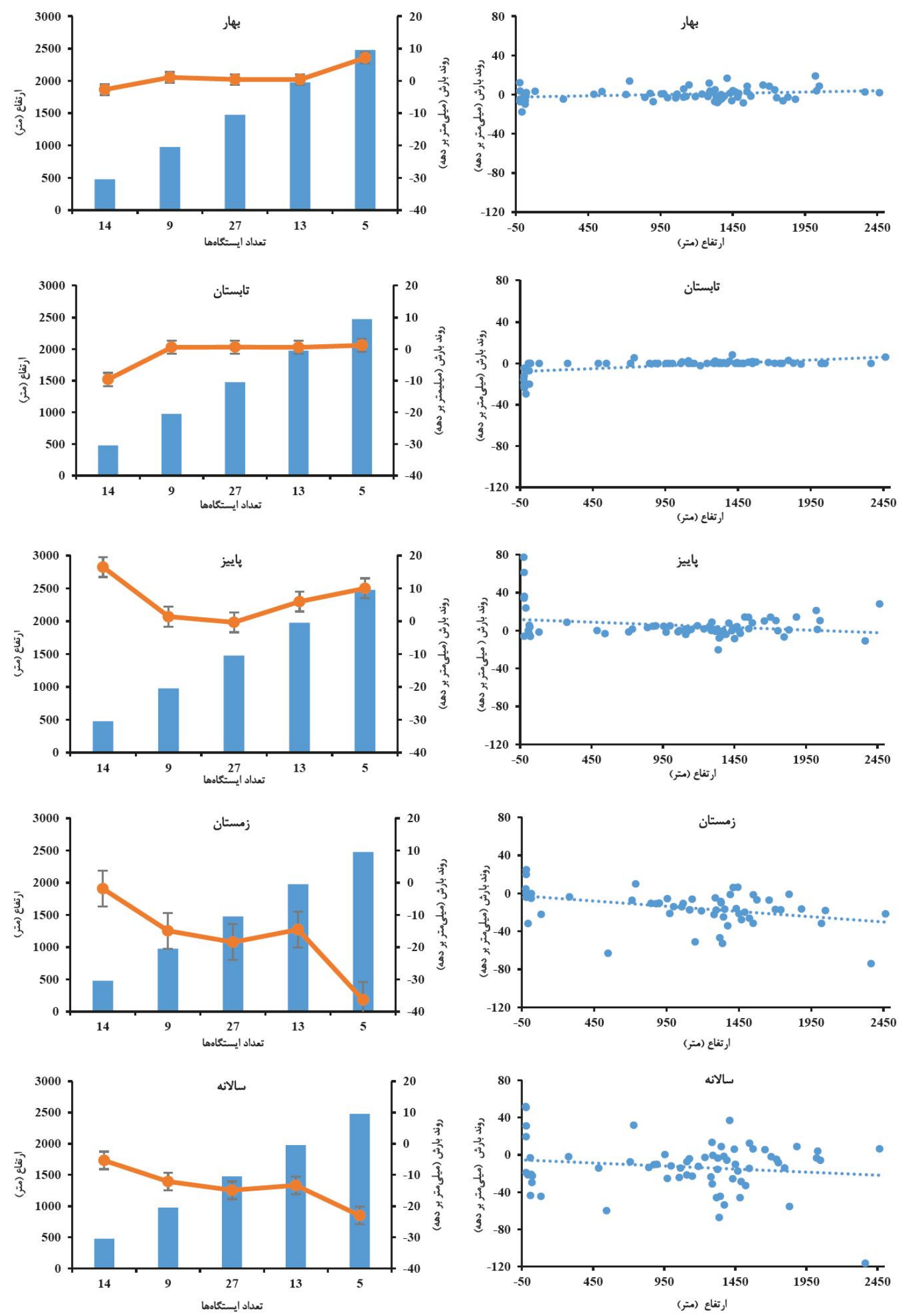

شكل 9. نمودارهاى ارتباط بين بارش و ارتفاع در مقياسهاى زمانى فصلى و سالانه 
جدول r. ضرايب تعيين (R) و همبستخى (r) رابطه متغيرهاى اقليمى و ارتفاع در مقياس فصلى و سالانه

\begin{tabular}{|c|c|c|c|c|c|c|c|c|c|c|}
\hline \multicolumn{2}{|c|}{ ساليانه } & \multicolumn{2}{|c|}{ مستان } & \multicolumn{2}{|c|}{ باييز } & \multicolumn{2}{|c|}{ 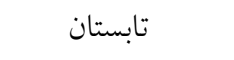 } & \multicolumn{2}{|c|}{ بهار } & \multirow{2}{*}{ متغييرهاى اقليمى } \\
\hline $\mathrm{R}^{2}$ & $\mathrm{r}$ & $\mathrm{R}^{2}$ & $\mathrm{r}$ & $\mathrm{R}^{2}$ & $\mathrm{r}$ & $\mathrm{R}^{2}$ & $\mathrm{r}$ & $\mathrm{R}^{2}$ & $\mathrm{r}$ & \\
\hline 01009 & $-\circ / \circ \wedge^{\mathrm{ns}}$ & & - & $\circ / 0 Y_{0}$ & $-0 / /\left.\right|^{k n s}$ & $\circ / \circ \circ \wedge$ & $-\circ / \circ q^{n s}$ & $\circ / 0 \circ \circ$ & $-0 /\left.0\right|^{\mathrm{ns}}$ & تبخير تشت، Ep \\
\hline $0 / 009$ & $-\circ / \circ q^{n s}$ & $0 / 199$ & $\circ / 4 Q^{* * *}$ & $\circ / 0 V Y$ & $-\circ / T V^{*}$ & $\circ / 0 V 9$ & $-\circ / T V^{*}$ & OOYT & $-\circ / / Q^{\mathrm{ns}}$ & دماى ميانكين، \\
\hline \% TV & $-\circ / / V^{n s}$ & $0 / 090$ & $\circ \mu_{0}^{* * *}$ & $0 / 094$ & $-\circ / T Q^{*}$ & O/०イ & $-\circ / Y_{\circ} \mathrm{ns}$ & ०/०म & $-0 / 19 \mathrm{~ns}$ & دماى حداقل، Tmin \\
\hline.$/ 014$ & $\circ / r^{\mathrm{ns}}$ & $\circ / \Delta \mu_{0}$ & $\circ / M^{* * *}$ & ०/०० & $\circ / \circ \Delta^{\mathrm{ns}}$ & $\circ / 040$ & $-\circ / Y I^{*}$ & $0 / 014$ & $\circ / r^{\mathrm{ns}}$ & دماى حداكثر، Tmax \\
\hline ०/O०Y & $\circ / \circ Q^{\mathrm{ns}}$ & $0 /$ YG० & $-0 /\left.0\right|^{* * *}$ & $\circ / 0 \wedge \varphi$ & $\circ / Y q^{*}$ & $\circ / 0 \circ 4$ & $\circ / \circ \mathrm{Vns}^{\mathrm{ns}}$ & $\circ / \circ \circ Y^{k}$ & $\circ / \circ \varphi^{\mathrm{ns}}$ & رطوبت نسبى، RH \\
\hline.$/ 0$ rq & $-\circ / I V^{n s}$ & $\circ / \circ 09$ & $\circ / Y Y^{*}$ & ०/०० & $-\circ / \circ \Delta^{\mathrm{ns}}$ & $\circ /$ rgr & $-0 / 01^{* * *}$ & o/ort & $-\circ / \backslash \wedge^{\mathrm{ns}}$ & ساعات آفتابى، SD \\
\hline$\circ / 0 \circ Y$ & $\circ / \circ Q^{\mathrm{ns}}$ & $0 / 009$ & $\circ / \circ \wedge^{\mathrm{ns}}$ & $\circ / \circ \circ 4$ & $-0 / 0 \varphi^{\mathrm{ns}}$ & ०००० & $-\circ / \circ Y^{\mathrm{ns}}$ & $0 / 001$ & $\circ / \circ \mu^{\mathrm{ns}}$ & سرعت باد، W \\
\hline $0 / 0 Y G$ & $-0 / / \varphi^{\mathrm{ns}}$ & $0 / N F$ & $-\circ / \Lambda^{* *}$ & $0 / 04 Y$ & $\circ / \Gamma \Delta^{*}$ & OMYA & $\circ / \Delta V^{n s}$ & $0 / 099$ & $0 / T 4^{*}$ & بارش، P \\
\hline
\end{tabular}

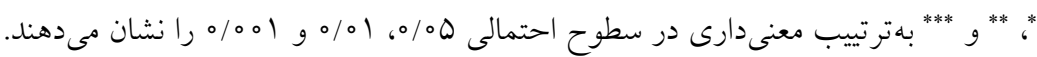

س (p=0/ غيرمعنى دار بوده است، درحالى كه در فصـل زمسـتان

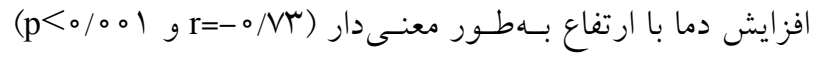
تشديد شده است و مناطق مرتفع افزايش دماى حداكثر بيشترى را در فصل زمستان داشتهاند. در فصل تابسـتان، افـزايش شـيب

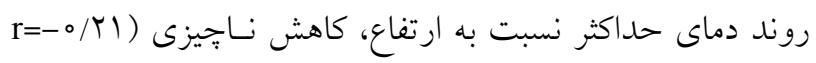

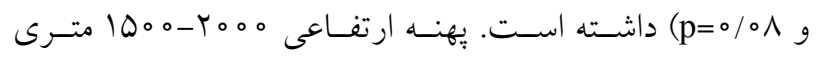
بيشترين نرخ افزايش دماى حداكثر در فصل زمستان را در مدت مrال اخير داشته است. بيشتر ايستخاههاى موجود در ايسن دامنـه ارتفـاعى (زنجـان،

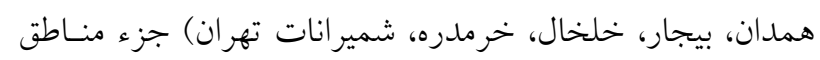
با اقليم سرد كشور محسوب مىشوند كه به اين ترتيـب بـهنظـر مىرسد اين مناطق دستخوش تغيير اقليم و گرم شدن زيـاد در فصل زمستان بوده است. بررسى رابطه روند تغييرات دما با ارتفاع در كوههاى تيانشان

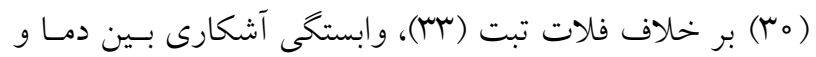
ارتفاع نشان نداد، كه با نتـايج ايسن بـزّوهش در مقيـاس سـالانه مطابقت دارد. درك مكانيسم محرى گرمايش وابسته بـه ارتفــاع براى توصـيف تغييـرات منطقـهاى گرمـايش نسـبت بـهـ ارتفـاع ضرورى است. تغيير آلبيدو، يوشش ابرها، ريزگردها، بخـار آب و فلاكسس تشعشـع را بـه كرمـايش وابسـته بـه ارتفــاع مـرتبط

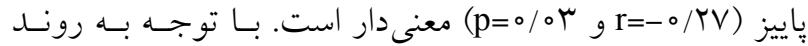
افزايشى دما در كشور در اين مقيـاسهـاى زمـانى، بـا افـزايش ارتفاع نرخ افزايش دماى ميانخين با كاهش ناجيزى روبهرو بوده است. ليكن، در فصل زمستان نرخ افزايش دماى ميانگين بهطور

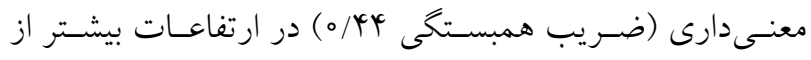
مناطق يست بوده است (جدول Y). متوسط نرخ افـزايش دمـاى

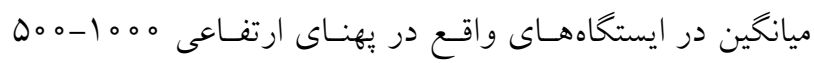
مترى در مقياسهاى زمانى مختلف بهجز زمستان، بيشتر از ديخر دامنه هاى ارتفاعى است. در فصل زمستان بيشترين افزايش دماى

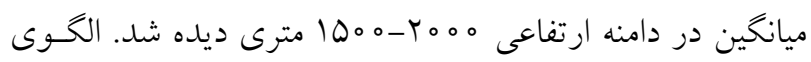
تغييرات دماى حـداقل نسـبت بـه ارتفـاع در مقيـاس فصـلى و

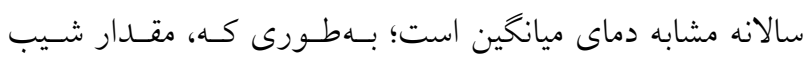
تغييرات دماى حداقل در طول مدت مورد مطالعه در مقياسهاى مختلف زمانى بهجز زمستان نسبت به ارتفاع روند كاهشى داشته

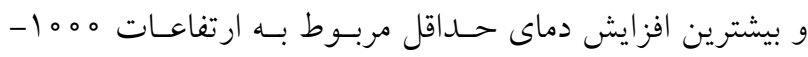
ماست (شكل (l). بررسى ارتبـاط دمـاى حــداكثر بـا ارتفــاع (شـكل ه) نشـان

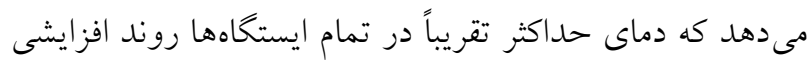

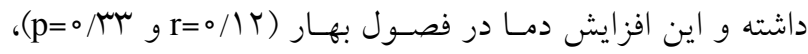

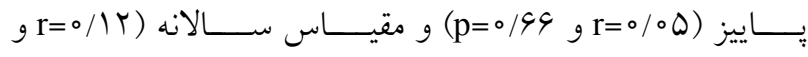




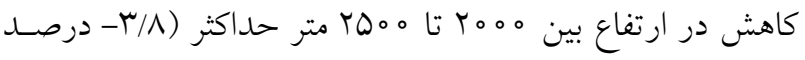

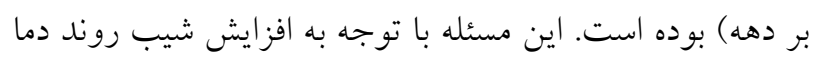

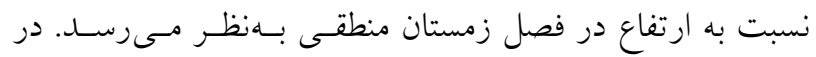

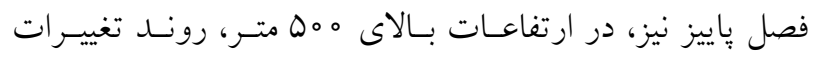

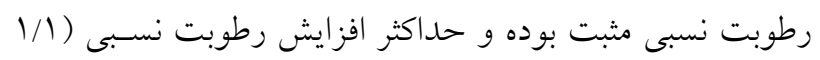

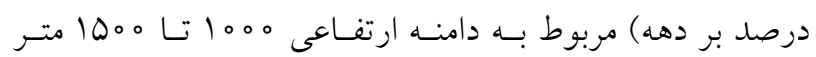

$$
\text { ارتباط روند ساعات آفتابى - ارتفاع }
$$

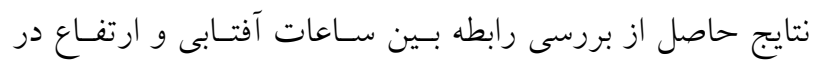

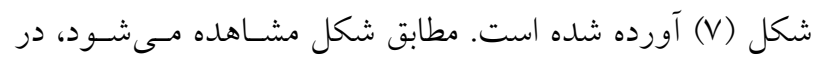

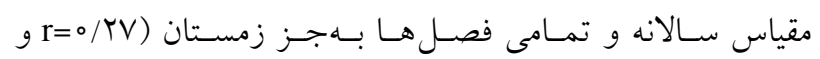
p=0/oV V

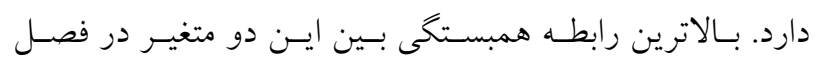

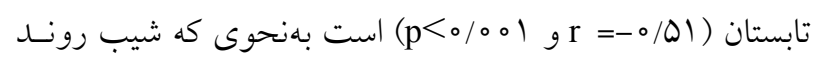

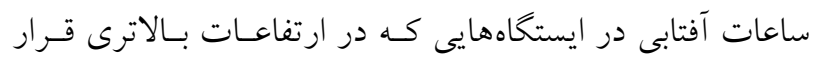
دارند، كاهش معنى دار بيشترى نسبت به مناطق همـوارتر داشـته

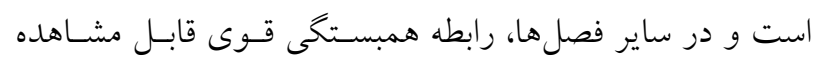

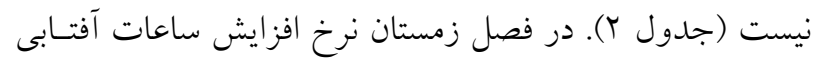
در ارتفاعات بيشتر از مناطق داراى ارتفاع كمتر است (شكل لإن).

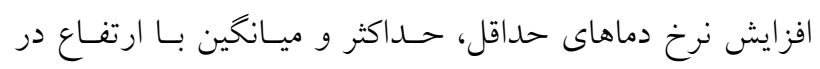

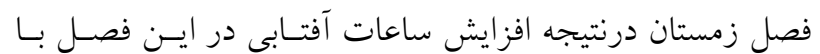

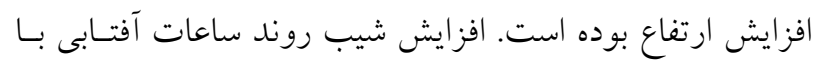

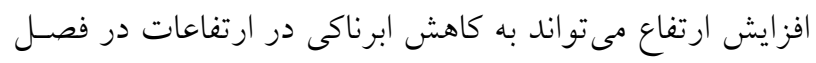

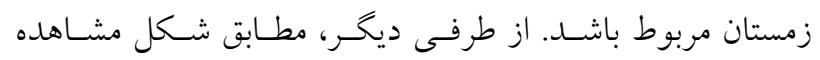

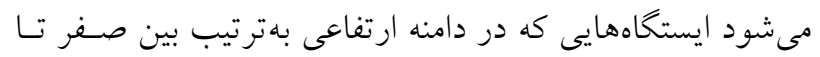

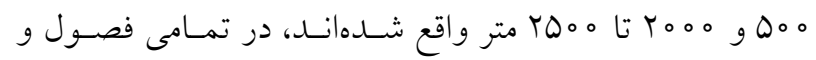

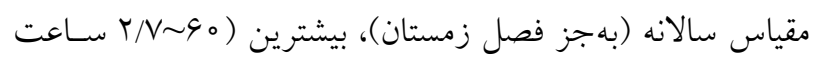

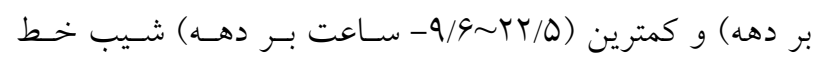

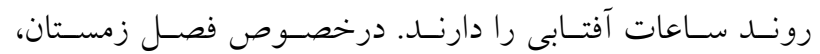

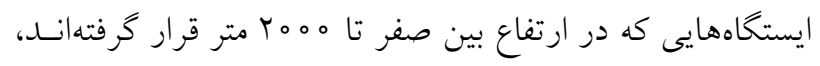

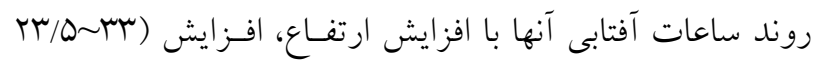

دانستهاند (Y) (Y). زمانى كه خط برف به ارتفاعـات بـالاتر صعود كند، درنتيجه كاهش يوشش برف در ارتفاعـات و تغييـر آلبيـدو

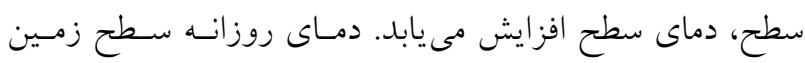

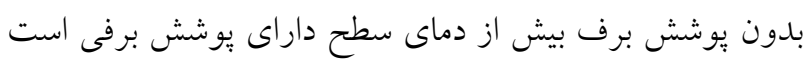

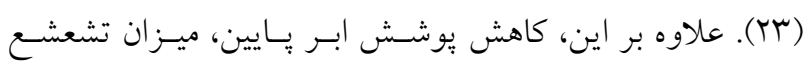

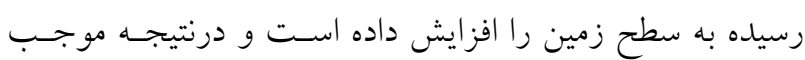
افزايش دماى سطح زمين مى زشود (سT).

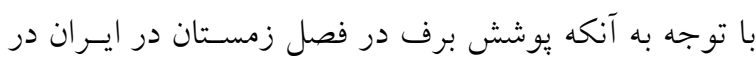

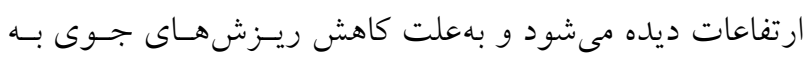

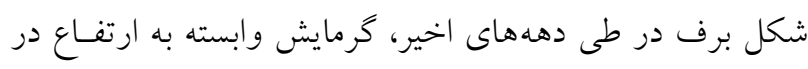

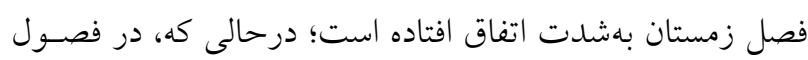

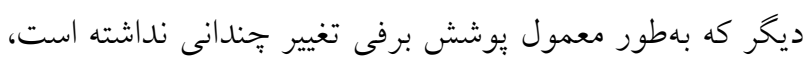

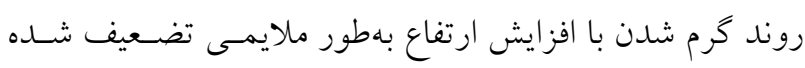

$$
\text { ارتباط روند رطوبت نسبى - ارتفاع }
$$

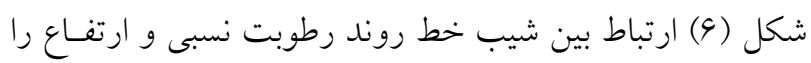

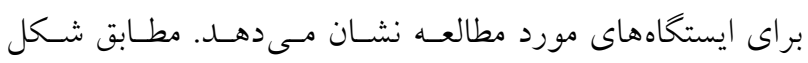

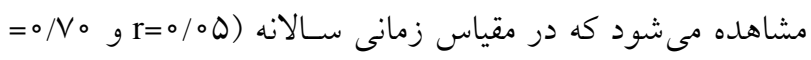

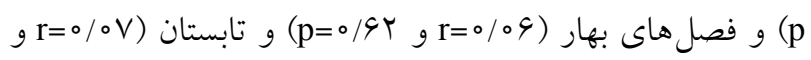
p=0/09

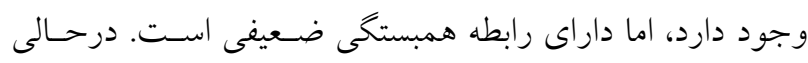

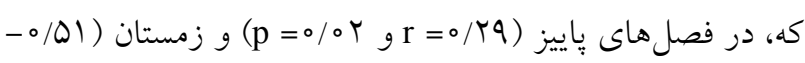

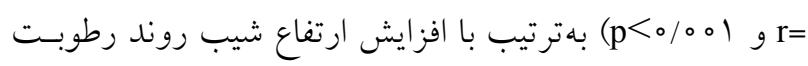

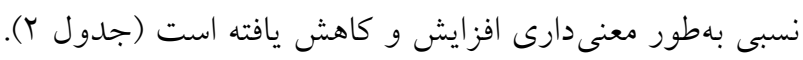

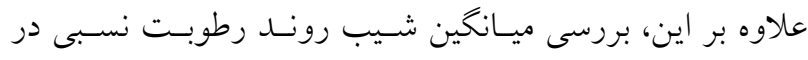

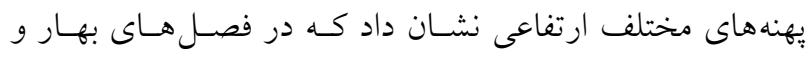

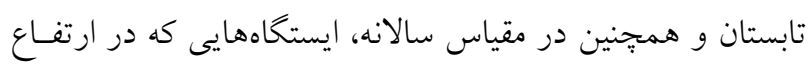

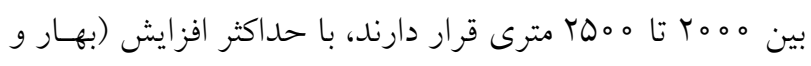

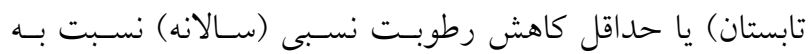

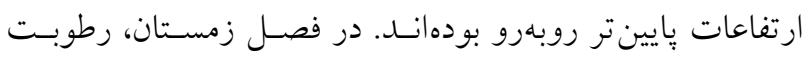

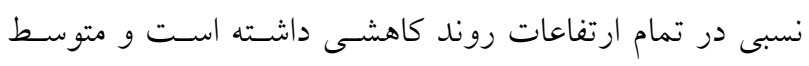




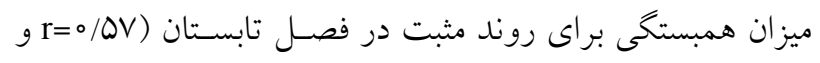

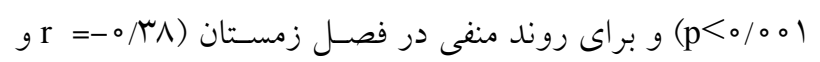

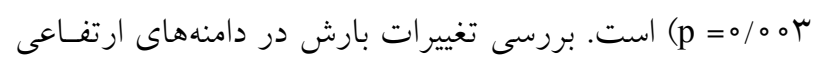

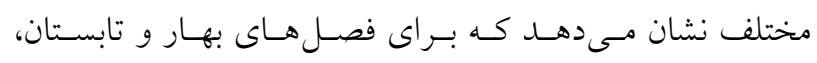

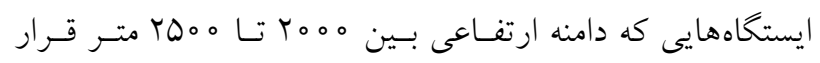

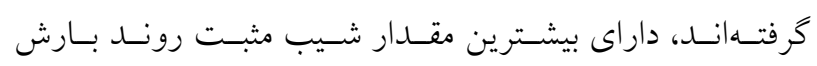

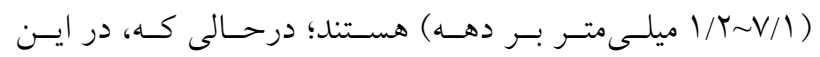

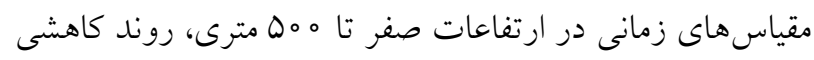
بارش ديده مىشود. در فصل زمستان و در مقياس سالانه متوسط شيب بارش درد در همه دامنههاى ارتفاعى منفى بوده و بهترتيب ايستخاههايى كه در

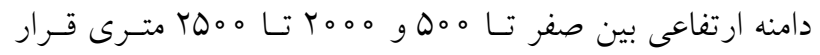

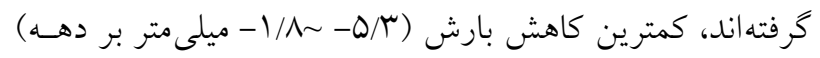

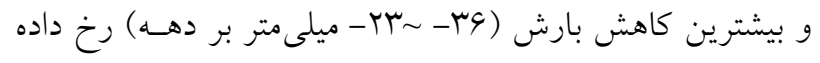
است. شيب روند بارش در اغلب ايستاهها در فصل ياييز مثبت

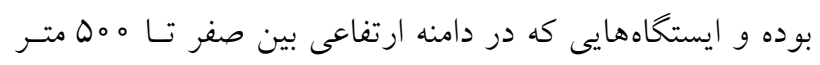

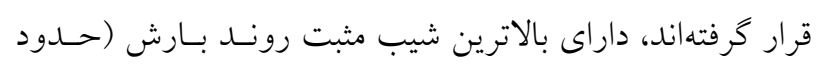

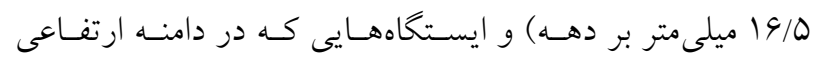

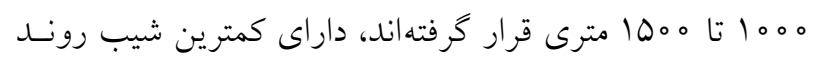

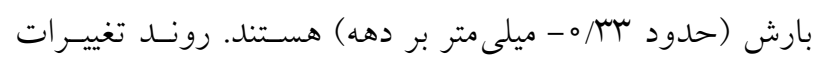

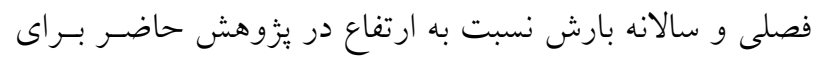

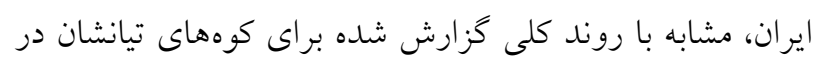

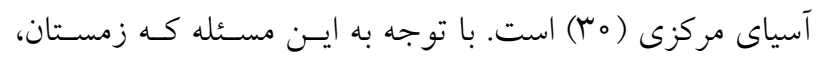

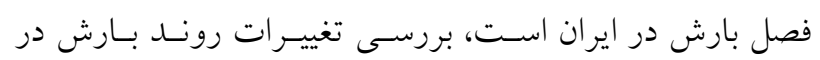

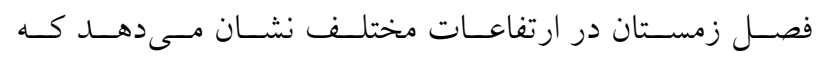

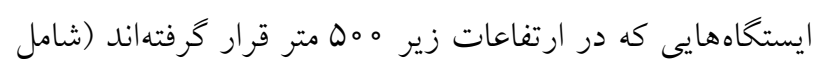

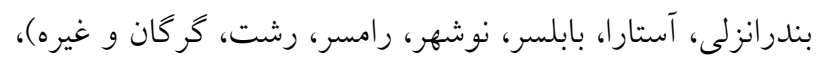

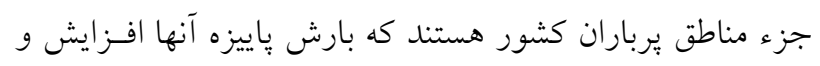

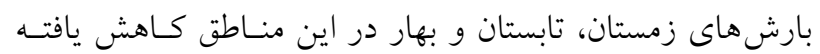

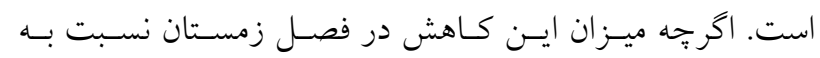
كاهش در ساير ارتفاعات، نـاجيز بـوده اسـت. لـيكن، در ميـان

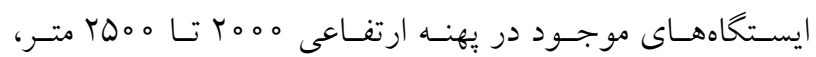

ساعت بر دهه) مى يابد و پِس از آن براى ايستخاههاى واقع شده

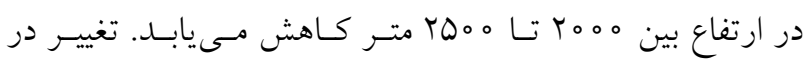

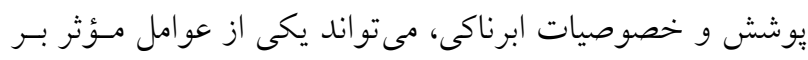

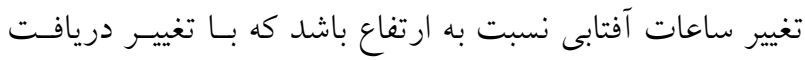
طول موجهاى كو تاه و بلند، بر بيلان انرزى سطحى اثر مى كذارد بهاب

$$
\text { ارتباط روند سرعت باد- ارتفاع }
$$

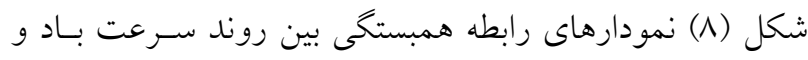

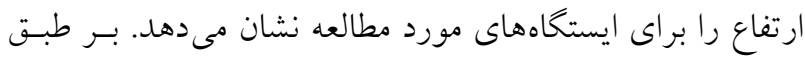

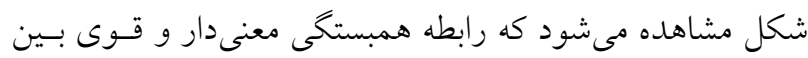

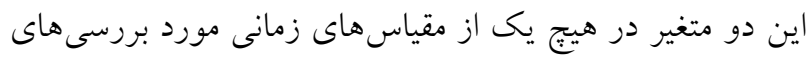

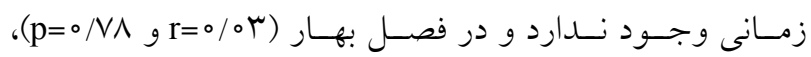

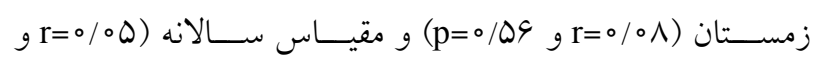

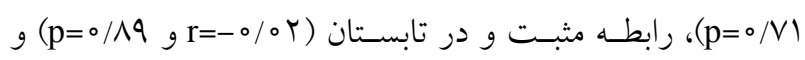

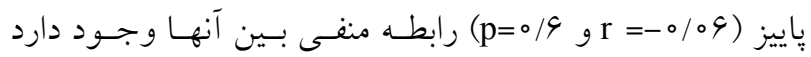

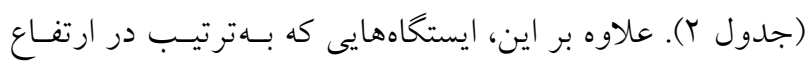

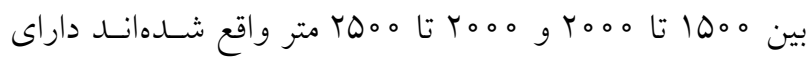

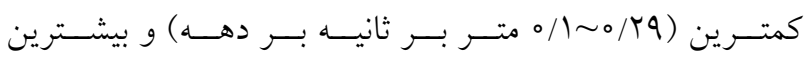

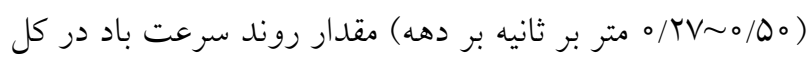

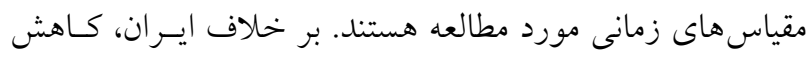

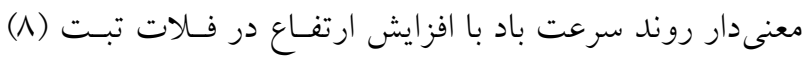
كزارش شد و كاهش سرعت باد به افزايش زبرى در ارتفاعـات مربوط دانسته شده است.

\section{ارتباط روند بارش - ارتفاع}

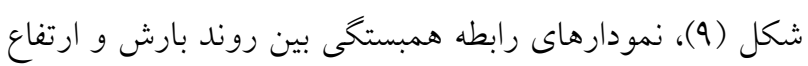
را براى منطقه مطالعاتى نشان مى دهند.

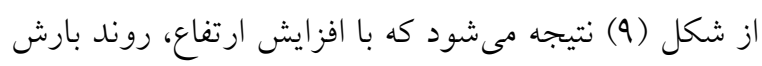
ايستخاهها براى فصل بهار (

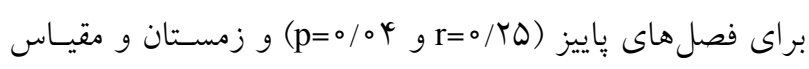
سالانه (p=-0/19 و pr=0/19) منفى است. بهنحوى كه، بيشترين 


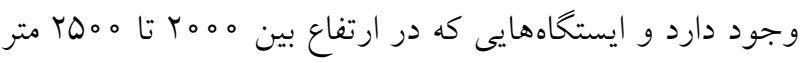
قرار دارند، با حداكثر افزايش (بهار و تابستان) يا حداقل كـاهش رطوبت نسبى (سالانه) نسـبت بـه ارتفاعـات يـايينتـر روبـهرو بودهاند. در مورد ساعات آنتابى، رابطه منفى بين روند اين متغير

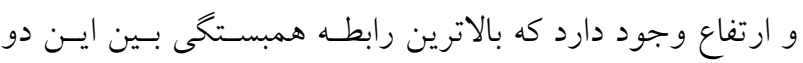
متغير در فصل تابستان است؛ بهنحوى كه، شيب رونسد سـاعات

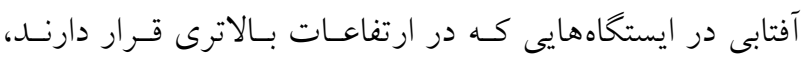
كاهش معنى دار بيشترى نسبت به مناطق هموارتر داشـته اسـت. در مورد سرعت باد نيز، رابطه معنىدارى بين اين متغير با ارتفاع وجود ندارد و ايستخاههايى كه بهترتيب در ارتفاع بين ه 100 تـا

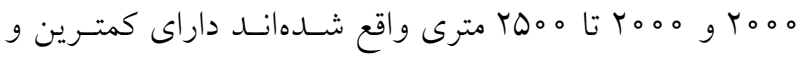
بيشترين مقدار رونــــ سـرعت بـاد در كـل مقيـاسهـاى زمـانى هستند. درخصوص بررسـى رابطـهـ بـين شـيب رونسا بـارش و

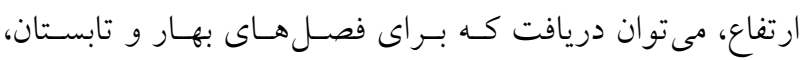

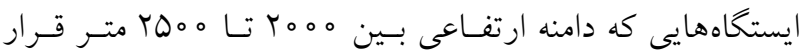
كرفتهاند، داراى بيشترين مقدار شيب مثبت روند بارش هسـتند. اما، براى فصل زمستان و مقياس سالانه، بهترتيب ايستخاههـايى

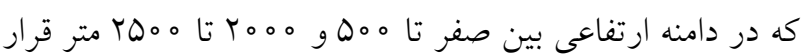
كرفتهاند، بيشترين و كمترين مقـدار شـيب رونـــ بـارش را دارا هستند. اين يُزوهش مىتواند بهعنوان يك مبنا براى يزّوهش هاى بيشتر در زمينه بررسى ساير عوامل جغرافيايى كه ممكسن اسـت بر روند متغيرهاى اقليمى تأثير گذار باشند، مـورد اسـتفاده قـرار كيرد.

مناطقى نظير اليخودرز، كوهرنـع، شـهركرد و آبعلى بــه جشــم مى خورد كه كاهش شديد بـارشهـاى زمسـتانه در ايسن منـاطق مى تواند بر آبدهى رودخانههاى كارون و جنوب غرب كشور اثر بخذارد.

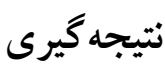

يزّوهش حاضر تلاشى بود بــــاى بررسـى رابطـهـ بـين ارتفــاع و شيب روند متغيرهاى اقليمسى بـراى 9 ايستخاه هواشناسـى در

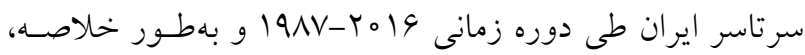
نتايج زير از اين بيزوهش قابل ارائه است: بهطور كلى، تبخير از تشت در ايران هم داراى روند افزايش هم روند كاهشى است. اما دما، سرعت باد و ساعات آفتـابى در بيشتر مناطق كشور داراى روند افزايشى است؛ بهنحــوى كـه، در فصل زمستان اين متغيرهـا بيشـترين افـزايش و مقــدار رطوبـت نسبى و باران بيشترين كاهش را نسبت به ساير فصـول در طـى دوره مطالعاتى داشتهاند. درخصوص ارتباط بين رونـــ تبخيـر از تشت و ارتفاع، نتايج ارتباط معنسى دارى بـين ايسن دو متغيـر در مقياس فصلى و سالانه نشان نداد و بيشترين شيب رونــ تبخيـر در فصل هاى بهار، تابستان و مقياس سالانه در ايستخاههـايى كـه.

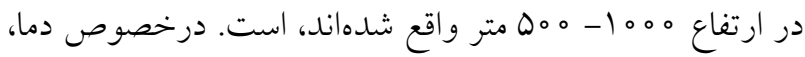
رابطه همبستخى منفى بين سنجههاى دما با ارتفاع وجـود دارد و

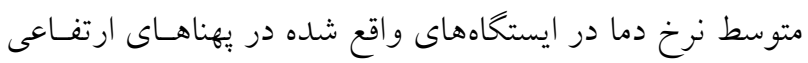

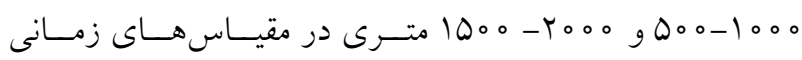
مختلف بيشترين مقدار را داشـتهانـد. در مـورد رطوبـت نسـبى، ارتباط مثبت و غيرمعنى دارى بين روند رطوبت نسبى و ارتفـاع

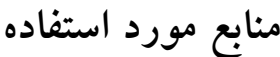

1. Beusekom, A. E, G. González and M. M. Rivera. 2015. Short-term precipitation and temperature trends along an elevation gradient in Northeastern Puerto Rico. Earth Interactions 19(3): 1-33.

2. Ceppi, P., S. C. Scherrer, A. M. Fischer and C. Appenzeller. 2012. Revisiting Swiss temperature trends 1959-2008. International Journal of Climatology 32: 203-213.

3. Chevuturi, A., A. P. Dimri and R. J. Thayyen. 2018. Climate change over Leh (Ladakh), India. Theoretical and Applied Climatology 131: 531-545.

4. Dinpashoh, Y., D. Jhajharia, A. Fakheri-Fard, V. P. Singh and E. Kahya. 2011. Trends in reference crop evapotranspiration over Iran. Journal of Hydrology 399: 422-433.

5. Ghasemi, A. R. 2015. Changes and trends in maximum, minimum and mean temperature series in Iran. Atmospheric 
Science Letters 16: 366-372.

6. Ghasemifar, E., M. Farajzadeh, M. C. Perry, Y. Ghavidel-Rahimi and A. AliAkbari-Bidokhti. 2018. Analysis of spatiotemporal variations of cloud fraction based on Geographic characteristics in Iran. Journal of the Earth and Space Physics 44(1): 103-124.

7. Gilbert, A. and C. Vincent. 2013. Atmospheric temperature changes over the 20th century at very high elevations in the European Alps from englacial temperatures. Geophysical Research Letters 40: 2102-2108.

8. Guo, X., L. Wang, L. Tian and X. Li. 2017. Elevation-dependent reductions in wind speed over and around the Tibetan Plateau. International Journal of Climatology 37: 1117-1126.

9. Intergovernmental Panel on Climate Change Fifth Assessment Report (IPCC). 2013 Summary for Policymakers: The Physical Science Basis, Contribution of Working Group I to the IPCC Fifth Assessment Report Climate Change.

10. Jahani, B., Y. Dinpashoh and M. Wild. 2018. Dimming in Iran since the 2000s and the potential underlying causes. International Journal of Climatology 38: 1543-1559.

11. Kendall, M. 1975. Rank correlation methods. Charles Griffin, London.

12. Khalili, A. and J. Rahimi. 2014. High-resolution spatiotemporal distribution of precipitation in Iran: a comparative study with three global-precipitation datasets. Theoretical and Applied Climatology 118: 211-221.

13. Kousari, M. R., H. Ahani and H. Hakimelahi. 2013. An investigation of near surface wind speed trends in arid and semiarid regions of Iran. Theoretical and Applied Climatology 114: 153-168.

14. Kousari, M. R., M. A. Asadi Zarch, H. Ahani and H. Hakimelahi. 2013. A survey of temporal and spatial reference crop evapotranspiration trends in Iran from 1960 to 2005. Climatic Change 120(1-2): 277-298.

15. Kousari, M. R., M. R. Ekhtesasi, M. Tazeh, M. A. Saremi Naeini and M. A. Asadi Zarch. 2011. An investigation of the Iranian climatic changes by considering the precipitation, temperature, and relative humidity parameters. Theoretical and Applied Climatology 103: 321-335.

16. Li, X., L. Wang, X. Guo and D. Chen. 2017. Does summer precipitation trend over and around the Tibetan Plateau depend on elevation? International Journal of Climatology 37: 1278-1284.

17. Mann, H. B. 1945. Nonparametric tests against trend. Econometrica 13: 245-259.

18. Modarres, R. and V. de Paulo Rodrigues da Silva. 2007. Rainfall trends in arid and semi-arid regions of Iran. Journal of Arid Environments 70: 344-355.

19. Ohmura, A. 2012. Enhanced temperature variability in high-altitude climate change. Theoretical and Applied Climatology 110: 499-508.

20. Pepin, N. and J. Lundquist. 2008. Temperature trends at high elevations: patterns across the globe. Geophysical Research Letters 35: L14701.

21. Pepin, N., R. S. Bradley, H. F. Diaz, M. Baraer, E. B. Caceres, N. Forsythe, H. Fowler, G. Greenwood, M. Z. Hashmi, X. D. Liu, J. R. Miller, L. Ning, A. Ohmura, E. Palazzi, I. Rangwala, W. Schöner, I. Severskiy, M. Shahgedanova, M. B. Wang, S. N. Williamson and D. Q. Yang. 2015. Elevation-dependent warming in mountain regions of the world. Nature Climate Change 5: 424-430.

22. Rahimzadeh, F., A. Sanchez-Lorenzo, M. Hamedi, M. C. Kruk and M. Wild. 2015 New evidence on the dimming/brightening phenomenon and decreasing diurnal temperature range in Iran (1961-2009). International Journal of Climatology 2065-2079.

23. Scherrer, S., P. Ceppi, M. Croci-Maspoli and C. Appenzeller. 2012. Snow albedo feedback and Swiss spring temperature trends. Theoretical and Applied Climatology 110: 509-516.

24. Sen, P. K. 1968. Estimates of the regression coefficient based on Kendall's tau. Journal of the American Statistical Association 63: 1379-1389.

25. Shadmani, M., S. Marofi and M. Roknian. 2012. Trend Analysis in Reference Evapotranspiration Using MannKendall and Spearman's Rho Tests in Arid Regions of Iran. Water Resources Management 26: 211-224.

26. Shi, X. H. and X. D. Xu. 2008. Interdecadal trend turning of global terrestrial temperature and precipitation during1951-2002. Progress in Natural Science 18(11): 1383-1393.

27. Soroush, F., F. Fathian, F. S. H. Khabisi and E. Kahya. 2020. Trends in pan evaporation and climate variables in Iran. Theoretical and Applied Climatology. https://doi.org/10.1007/s00704-020-03262-9.

28. Theil, H. 1950. A rank-invariant method of linear and polynomial regression analysis, Proceedings of the Koninklijke Nederlandse Akademie Wetenschappen, Series A Mathematical Sciences A53: 386-392.

29. Vuille, M., R. S. Bradley, M. Werner and F. Keimig. 2003. 20th century climate change in the tropical Andes: observations and model results. Climatic Change 59: 75-99

30. Xu, M., S. Kang, H. Wu and X. Yuan. 2018. Detection of spatio-temporal variability of air temperature and precipitation based on long-term meteorological station observations over Tianshan Mountains. Central Asia. Atmospheric Research 203: 141-163.

31. Yan, L. B. and X. D. Liu. 2014. Has climatic warming over the Tibetan Plateau paused or continued in recent year? 
Journal of Earth Ocean Atmospheric Science 1(1): 13-28.

32. Yao, J., Y. Chen and Q. Yang. 2016. Spatial and temporal variability of water vapor pressure in the arid region of northwest China, during 1961-2011. Theoretical and Applied Climatology 123(3-4): 683-691.

33. You, Q., Y. Zhang, X. Xie and F. Wu. 2019. Robust elevation dependency warming over the Tibetan Plateau under global warming of $1.5^{\circ} \mathrm{C}$ and $2{ }^{\circ} \mathrm{C}$. Climate Dynamics 53: 2047-2060.

34.Zeng, W., Z. Yu, S. Wu and J. Qin. 2016. Changes in annual, seasonal and monthly precipitation events and their link with elevation in Sichuan province, China. International Journal of Climatology 36(5): 2303-2322.

35. Zhang, X., L. Wang and D. Chen. 2019. How does temporal trend of reference evapotranspiration over the Tibetan Plateau change with elevation? International Journal of Climatology 39: 2295-2305. 


\title{
Investigation of the Relationship between Altitude and Trend Slope in Climate Variables in Iran during 1987-2016
}

\author{
F. Soroush* and F. Fathian ${ }^{1}$ \\ (Received: January 5-2020 ; Accepted: September 6-2020)
}

\begin{abstract}
In the present study, the spatial and temporal changes of climate variables such as pan evaporation (Ep), temperature $(\mathrm{T})$, relative humidity $(\mathrm{RH})$, sunshine duration $(\mathrm{SD})$, wind speed $(\mathrm{W})$ and precipitation $(\mathrm{P})$, as well as their relationship with altitude, were investigated. For this purpose, 68 meteorological stations with 30 years of data (1987-2016) throughout Iran on both seasonal and annual time scales were selected. Trend analysis of climate variables showed that over the past 30 years, most areas of Iran have become warmer and drier although all trends have not been significant. Investigation of the relationship between the trend slope of climate variables and altitude illustrated that there was no significant relationship between them during the study period on the annual time scale $(p>0.1)$. However, in winter, the rate of increase in $\mathrm{T}$ (minimum, maximum and mean temperatures) and $\mathrm{SD}(\mathrm{p}<0.1)$, as well as the rate of decrease in $\mathrm{P}$ $(p<0.01)$, was significantly enhanced by increasing the altitude. The increase in mean and maximum $T(p<0.1)$ and SD rates $(p<0.001)$ in summer were significantly lower in the highlands than in the lowlands. In autumn, the trend slopes of minimum and mean $\mathrm{T}(\mathrm{p}<0.05)$ were negatively correlated with altitude; in addition, the rates of increase in $\mathrm{P}$ and $\mathrm{RH}$ $(p<0.05)$ in the highlands demonstrated a sharper increase. It seems, therefore, that most changes in climate variables have occurred in both autumn and winter. The results also showed that in winter, the highest rates of increase in Ts were related to the altitude of 1500-2000 m; however, the highest decrease in P belonged to the altitude of $2000-2500 \mathrm{~m}$. In autumn, the highest rates of decrease in minimum and mean Ts had occurred in the altitude of 2000-2500 m; as well, he highest rate of increase in $\mathrm{P}$ was observed in the altitudes of both 0-500 $\mathrm{m}$ and 2000-2500 $\mathrm{m}$.
\end{abstract}

Keywords: Climate variables, altitude, trend slope, Iran.

1. Department of Water Engineering, College of Agriculture, Vali-e-Asr University of Rafsanjan, Iran Corresponding author, Email: f.soroush@vru.ac.ir 